\title{
Co-evolutions of terrestrial temperature and seasonal precipitation from the latest Pleistocene to the mid-Holocene in Japan: carbonate clumped isotope record of a stalagmite
}

Hirokazu Kato ( $\sim$ h.kato@eps.s.u-tokyo.ac.jp )

The University of Tokyo https://orcid.org/0000-0003-0512-3694

\section{Taiki Mori}

Chuo Kaihatsu Corporation

\section{Shota Amekawa}

University of Tokyo: Tokyo Daigaku

\section{Chung-Che Wu}

ETH Zürich

\section{Chuan-Chou Shen}

National Taiwan University

Akihiro Kano

The University of Tokyo

\section{Research article}

Keywords: Stalagmite paleoclimatology, Carbonate clumped isotope, Oxygen isotope, Paleotemperature, Paleoprecipitation, Latest Pleistocene, Holocene, Heinrich events, Hypsithermal, East Asian monsoons

Posted Date: November 1st, 2021

DOl: https://doi.org/10.21203/rs.3.rs-993823/v1

License: (9) This work is licensed under a Creative Commons Attribution 4.0 International License. Read Full License 


\section{Abstract}

Quantitative paleotemperature reconstruction is a challenging and important issue in terrestrial paleoenvironmental studies, for which carbonate clumped isotope $\left(\Delta_{47}\right)$ thermometry is a promising approach. Here we analyzed $\Delta_{47}$ values from 68 layers of OT02 stalagmite from Ohtaki Cave in central Japan, covering two separate time intervals $(2.6-8.8$ and $34.8-63.5 \mathrm{ka})$ to reconstruct temperature and meteoric $\mathrm{d}^{18} \mathrm{O}$ records. The average $\Delta_{47}$ temperature of the Holocene portion of this stalagmite was $16.3^{\circ} \mathrm{C} \pm 5.6^{\circ} \mathrm{C}, 6.6^{\circ} \mathrm{C} \pm 7.2^{\circ} \mathrm{C}$ higher than the average of the latest Pleistocene portion, which was $9.7^{\circ} \mathrm{C}$ $\pm 4.6^{\circ} \mathrm{C} . \Delta_{47}$ thermometry also revealed that the coldest intervals $\left(5^{\circ} \mathrm{C}-10^{\circ} \mathrm{C}\right)$ correspond to the Heinrich cooling events $\mathrm{H} 4-6$, and the warmest interval (up to $19.9^{\circ} \mathrm{C} \pm 6.0^{\circ} \mathrm{C}$ ) in middle Holocene (approximately 6-5 ka) accompanied by the Hypsithermal climate optimum. We also reconstructed past meteoric $\delta^{18} \mathrm{O}$ by subtracting the temperature effect from stalagmite $\delta^{18} \mathrm{O}$. Average meteoric $\delta^{18} \mathrm{O}$ was less negative in the Holocene (8.22\%o $\pm 0.99 \%$ VSMOW) than in the latest Pleistocene ( $8.81 \%$ $\pm 0.84 \%$ o). Over centennial timescales, meteoric $\delta^{18} \mathrm{O}$ was more negative during colder periods, such as Heinrich cooling events and the cooling event around $7 \mathrm{ka}$, and less negative in warmer periods, such as Hypsithermal warming. These relations indicated co-evolution of terrestrial paleotemperature and paleoprecipitation. A temperature dependency of ${ }^{18} \mathrm{O}$ fractionation from water to vapor is a likely reason for the negative correlation between temperature and meteoric $\delta^{18} \mathrm{O}$. Additionally, it is possible that increasing lower $\delta^{18} \mathrm{O}$ precipitation from East Asian winter monsoon (EAWM) has decreased the averaged meteoric $\delta^{18} \mathrm{O}$ in colder periods. These temperature effects on meteoric $\delta^{18} 0$ occur in opposite directions to fractionation between water and the stalagmite $\delta^{18} \mathrm{O}$, explaining the small amplitudes of changes observed in the $\delta^{18} \mathrm{O}$ of Japanese stalagmites.

\section{Introduction}

The oxygen isotopic composition of stalagmite calcite $\left({ }^{18} \mathrm{O}_{c}\right)$ is a key source of information for terrestrial paleoclimates. Nevertheless, paleoclimatic interpretation of stalagmite $\delta^{18} \mathrm{O}_{\mathrm{C}}$ should consider two main controlling factors: the temperature of calcite formation and the oxygen isotopic composition of cave drip water $\left(\delta^{18} \mathrm{O}_{\mathrm{W}}\right)$. The latter factor also involves changes in some meteorological conditions, such as monsoon intensity, moisture trajectory, and precipitation seasonality. Although previous stalagmite studies in East Asia often emphasized the so-called "amount effect" or the change in moisture sources (e.g., Wang et al., 2001) as a cause of changes in $\delta^{18} \mathrm{O}_{C}$, limited attention has been paid to the role of temperature changes on the stalagmite $\delta^{18} \mathrm{O}_{\mathrm{C}}$ records (e.g., Tremaine et al., 2011; Meckler et al., 2015).

The importance of temperature signals was reaffirmed for late Pleistocene to middle Holocene stalagmites from Mie and Gifu Prefectures, central Japan, located at the eastern margin of the East Asian monsoon regime (Mori et al., 2018; Fig. 1). These stalagmites exhibit notably smaller amplitudes of variation in $\delta^{18} \mathrm{O}_{\mathrm{C}}$ than comparable Chinese cave records; hence, the glacial/interglacial contrast within 
these stalagmites can be accounted for by a typical warming temperature of $9^{\circ} \mathrm{C}$ from the last glacial maximum (LGM) to the mid-Holocene (Mori et al., 2018). This estimated temperature change is comparable with other paleoclimate studies using stalagmites and lake and marine deposits around the Japanese Islands (e.g., Nakagawa et al., 2002; Kawahata et al., 2011; Kigoshi et al., 2014; Uemura et al., 2016). Mori et al. (2018) concluded that climate control on $\delta{ }^{18} O_{W}$ values was insignificant for Japanese caves, perhaps because of their proximity to moisture sources in the Pacific.

Changes in temperature and precipitation are principal factors influencing terrestrial climate and are intimately connected. To reconstruct their co-evolution, their signals should be divided quantitatively. Regrettably, it is challenging to determine the relative importance of the two fundamental controls on stalagmite $\delta^{18} \mathrm{O}_{\mathrm{C}}$, temperature and $\delta^{18} \mathrm{O}_{W}$, using conventional isotopic compositions alone. An independent approach to estimate paleotemperature is carbonate clumped isotope $\left(\Delta_{47}\right)$ thermometry (e.g., Ghosh et al., 2006; Eiler et al., 2007), which does not require assumptions regarding $\delta^{18} O_{W}$ values.

In our previous study (Kato et al., 2021), we measured $\Delta_{47}$ values from 50 layers of a well-dated stalagmite Hiro-1 (4.5-18.1 ka) from Maboroshi Cave in Hiroshima Prefecture, southwestern Japan (Shen et al., 2010; Hori et al., 2013, 2014; Fig. 1). We revealed terrestrial temperature changes after the LGM to the mid-Holocene, except for two hiatuses around 12.8-11.4 and 10.8-7.7 ka and some layers in which $\Delta_{47}$ and $\delta^{18} \mathrm{O}_{\mathrm{C}}$ were significantly disturbed by kinetic isotope effect (KIE) because of dry cave conditions. The difference between the average $\Delta_{47}$ temperatures in the pre-Holocene (18.0-16.0 ka) and mid-Holocene $(7.7-4.9 \mathrm{ka})$ was $8.3^{\circ} \mathrm{C} \pm 4.2^{\circ} \mathrm{C}$, which is comparable with other estimates for the difference between the LGM and the Holocene from the two Japanese caves, Gyokusendo $\left(8.2^{\circ} \mathrm{C}, 0\right.$ versus 26 ka; Uemura et al., 2016) and Kiriana ( $\left({ }^{\circ} \mathrm{C}, 7\right.$ versus 24 ka; Mori et al., 2018). The $\Delta_{47}$ values of Hiro-1 exhibit an abrupt warming around 6.3-4.9 ka, which likely corresponds to the Hypsithermal event (e.g., Wanner et al., 2008), but the record during the corresponding Heinrich cooling event (HS1) was unavailable because of strong influences of KIE related to dry cave conditions (Kato et al., 2021). We also reconstructed changes in the meteoric water $\delta^{18} \mathrm{O}_{\mathrm{MW}}$ from the stalagmite $\delta^{18} \mathrm{O}$ and the $\Delta_{47}$ temperature, finding a correlation between $\delta^{18} \mathrm{O}_{\mathrm{MW}}$ and $\Delta_{47}$ temperature. We show that the $\delta^{18} \mathrm{O}_{\mathrm{MW}}$ largely shifted positively because of changes in vapor trajectory to the region due to the Holocene transgression of the Seto Inland Sea (SIS; Fig. 1b; Kato et al., 2021).

In this study, we analyzed the $\Delta_{47}$ values of the OT02 stalagmite (2.6-8.8 and 34.8-63.5 ka; Mori et al., 2018) from Ohtaki Cave (Fig. 1) to obtain a longer climatic record in Japan (back to 63 ka) including four periods of Heinrich cooling that have not yet been elucidated in Japan. We discuss the co-evolution of terrestrial temperature and precipitation from the Late Pleistocene to Holocene, making comparisons with the results from the Hiro-1 stalagmite (Kato et al., 2021).

\section{Study Area And Material}




\subsection{Ohtaki Cave and the 0T02 stalagmite}

Ohtaki Cave ( $35^{\circ} 44^{\prime} \mathrm{N}, 136^{\circ} 59^{\prime} \mathrm{E} ; 400 \mathrm{~m}$ asl at the entrance) is located in central Gifu Prefecture, Honshu (Fig. 1). As measured at Nagataki (altitude: $430 \mathrm{~m}$ asl), a nearby meteorological station, the annual average rainfall over the latest 40 years was $3081 \mathrm{~mm}$. The region is wet year-round: $22.6 \%$ in spring (March-May), 36.0\% in summer (June-August), $24.6 \%$ in autumn (September-November), and $16.8 \%$ in winter (December-February). The 40 year mean annual average temperature is $11.5^{\circ} \mathrm{C}$, ranging from $-0.3^{\circ} \mathrm{C}$ in January to $23.9^{\circ} \mathrm{C}$ in August (Fig. 2a).

Ohtaki Cave has a total length of more than $1000 \mathrm{~m}$ (Yura, 2011) into the Permian limestone of the Mino Terrane (Kajita et al., 1971). It comprises three cave levels; stalagmites are best developed in the middle level, which is located $110 \mathrm{~m}$ underground. The cave has been modified by artificial tunnels for tourists, but the temperature in the cave remains stable at approximately $13.0^{\circ} \mathrm{C}$, which is higher than the annual mean temperature observed in the nearest weather observatory at Nagataki $\left(11.5^{\circ} \mathrm{C}\right)$. A larger amount of water seepage during summer likely elevates the cave water temperature throughout the year.

We analyzed A 140-mm-long stalagmite (OT02) collected $200 \mathrm{~m}$ from the cave entrance. U-Th ages and $\delta^{18} \mathrm{O}$ values from OT02 have been reported by Mori et al. (2018). The age model of OT02 was established on the basis of U-Th ages from 11 horizons using a Bayesian statistical model (StalAge; Scholz and Hoffman, 2011). A hiatus of $26 \mathrm{kyr}(8.8-34.8 \mathrm{ka}$ ) was recognized at a discontinuous surface at the 55 $\mathrm{mm}$ horizon (Mori et al., 2018). The age ranges of the upper and lower parts are 2.6-8.8 and 34.8-63.5 ka, respectively; however, the age model of the upper portion of OT02 includes a relatively large uncertainty (up to $\pm 2.5 \mathrm{kyr}$; Mori et al., 2018). The lower part of OT02 stalagmite records four Heinrich cooling events ( $\mathrm{H} 4-6$ including $\mathrm{H} 5.2$ ).

\subsection{Climatic and hydrological settings of Ohtaki and Maboroshi Caves}

Two major moisture sources to Japan are the Pacific Ocean and the Japan Sea, from which the East Asian summer and winter monsoons (EASM and EAWM, respectively) bring moisture mainly by warm southerly winds and cold northerly winds, respectively. The climate of Japan is characterized by clear seasonality because the East Asian summer/winter monsoons migrate across the region. Consequently, the precipitation source switches seasonally between the Pacific Ocean in summer and the Japan Sea in winter (Fukui, 1977). On the Pacific side of the central mountains in Japan, including the sites of Ohtaki Cave (OT02) and Maboroshi Cave (Hiro-1), the EASM delivers the majority of the annual precipitation to the Pacific side of Japan. During the winter, the cold and dry EAWM winds acquire moisture from the Tsushima Warm Current, which blows into the Japan Sea. Most moisture from the Japan Sea side is then released as heavy snow and rainfall on the Japan Sea coast, whereas residual moisture generates comparatively short snow and rainfall on the Pacific side. Consequently, less negative $\delta^{18} \mathrm{O}_{\mathrm{MW}}$ values are observed during the warm season, and more negative $\delta^{18} \mathrm{O}_{\mathrm{MW}}$ values are observed during the cold season in several areas in Japan. 
Hori et al. (2009) collected meteoric water at monthly intervals at Nagaya (Okayama Prefecture), located $20 \mathrm{~km}$ east of the site of Hiro-1, in 2005-2007. $\delta^{18} \mathrm{O}_{\mathrm{MW}}$ exhibited less negative values from April to October $(-7.1 \%$ o $\pm 1.4 \%$ o in amount-weighted average) and more negative values from November to March (-9.7\% $\pm 1.4 \%$; Hori et al., 2009; Fig. 2d).

Mori et al. (2018) collected 13 samples of cave drip water at stalagmite OT02 from July 2013 to November 2015, as well as 137 separate rain events from November 2013 to September 2015 at Ohgaki City (altitude $10 \mathrm{~m}$ ), located $60 \mathrm{~km}$ southwest from upstream along the major moist trajectory during the EASM season. In Ohgaki, $\delta^{18} \mathrm{O}_{\mathrm{MW}}$ from 2013 to 2015 shows a trend similar to that in Nagaya (Mori et al., 2018); however, the $\delta^{18} \mathrm{O}_{\mathrm{MW}}$ values at Ohgaki show clearer seasonal differences, i.e., less negative values from March to November ( $-5.7 \%$ o $\pm 2.3 \%$ in amount-weighted average) and more negative values from December to February $(-10.8 \% \circ \pm 2.1 \%$; Mori et al., 2018 ; Fig. $2 \mathrm{c})$. The drip water $\delta^{18} \mathrm{O}$ value at Ohtaki $\left(-8.3 \%\right.$ on average) is clearly lower than the average $\delta^{18} \mathrm{O}_{\mathrm{MW}}$ value at Ohgaki $(-6.4 \%$; Mori et al., 2018). This discrepancy is explained by locations along the dominant path of moisture trajectory and differences in altitude; Ohtaki Cave is further from the Pacific and at a higher altitude ( $400 \mathrm{~m}$ asl) than Ohgaki (10 m asl). Asai et al. (2014) investigated monthly $\delta^{18} \mathrm{O}_{\mathrm{MW}}$ values at 11 locations on Mt. Ontake (1030-2750 $\mathrm{m}$ asl), $45 \mathrm{~km}$ east-northeast of Ohtaki Cave, in 2003-2005. The $\delta^{18} \mathrm{O}_{\mathrm{MW}}$ values in the region were highest in spring (April-May; approximately $-10 \%$ o to $-8 \%$ ), lowest in winter (JanuaryFebruary; approximately $-15 \%$ o to $-14 \%$ ), and moderate during the summer (Asai et al., 2014). Although the altitudes of these sites (Nagaya, Ohgaki, and Ontake) differ significantly from that of Ohtaki Cave, there is a common trend in that the most negative $\delta^{18} \mathrm{O}_{\mathrm{MW}}$ values were observed in winter. Since Ohgaki is located upstream of Ohtaki along the major moisture trajectory of the region, the seasonal pattern of $\delta^{18} \mathrm{O}_{\mathrm{MW}}$ around Ohtaki Cave is likely most similar to that in Ohgaki.

A major difference between the climatic settings of Maboroshi Cave (Yuki) and Ohtaki Cave (Nagataki) is a seasonal bias of precipitation amount. In Yuki, precipitation during the warmer 7 months (AprilOctober) accounts for $78 \%$ of the annual total, which is more than three times the precipitation in the other 5 months (November-March; 22\%). Particularly, precipitation during the coldest 3 months (December-February) is limited to only $10 \%$ of the annual total and the yearly variation is also very limited in these months (Fig. 2d). In the region of Maboroshi Cave, the Chugoku Mountains (1729 m asl) obstruct the winter rain/snowfall from the Japan Sea side. Conversely, in Nagataki (near Ohtaki Cave), precipitation during the three winter months (December-February) accounts for $16.8 \%$ of annual precipitation and yearly variations in winter precipitation are far larger than those in Yuki (Fig. 2c and d). Consequently, the amount ratio of winter and annual precipitation is also an important factor controlling the annual average $\delta^{18} \mathrm{O}_{\mathrm{MW}}$ values at Ohtaki Cave.

Figure 3 shows the standard deviation of monthly average temperature ( $1 \sigma ;$ black bold line) and the correlation coefficients between annual and monthly average temperatures ( $R$; dashed line) in Nagataki (Fig. 3a) and Yuki (Fig. 3b) over the last 40 years. It also shows the impact of monthly temperatures on 
the annual average $\left({ }^{\circ} \mathrm{C} /{ }^{\circ} \mathrm{C}\right.$; gray line), i.e., the regression slope between monthly and annual temperature. In Nagataki (near Ohtaki Cave), temperature deviations tend to be large in the colder season (DecemberApril) and small in the warmer season (May-October) (the largest deviation occurs in February and November and the smallest in June). The correlation coefficient (R) of annual and monthly temperatures is large in February-May and September-October and smallest in July-August, the warmest months (Fig. 2). This indicates that summer temperature is the least important factor influencing the annual average temperature in Nagataki. These relations will be discussed in section 5.4.

\section{Method}

\subsection{Stable oxygen isotope compositions normalized to seawater values}

Mori et al. (2018) already reported the stable oxygen isotope compositions for 644 layers (at $0.2 \mathrm{~mm}$ intervals) from the growth axis of the 0T02 stalagmite. $\delta^{18} \mathrm{O}$ values in the OT02 stalagmite range from $-8.2 \%$ o to $-6.3 \%$ o. We used their $\delta^{18} \mathrm{O}$ data in which it is assumed that the oxygen isotope values of drip water and 0T02 $\left(\delta^{18} \mathrm{O}_{\text {Ото2 }}\right)$ were influenced by seawater $\delta^{18} \mathrm{O}_{\mathrm{SW}}$ change because the hydrological origin of moisture circulation in Japan is predominantly seawater. To correct the $\delta^{18} \mathrm{O}_{\text {Ото2 }}$ values, we accounted for the influence from $\delta^{18} \mathrm{O}_{\mathrm{SW}}$ change $\left(\Delta^{18} \mathrm{O}_{\mathrm{SW}}\right)$ following Mori et al. (2018) as follows:

$\Delta^{18} \mathrm{O}_{\mathrm{SW}}=\left(\delta^{18} \mathrm{O}_{\text {foram }}-3.26\right) * 1 /(5.03-3.26)(1)$

where $\delta^{18} \mathrm{O}_{\text {foram }}$ is the time series from deep Pacific benthic forams reported by Lisiecki and Stern (2016), which changes from $+5.03 \%$ o during the LGM to $+3.26 \%$ o. Equation 1 converts $\delta^{18} \mathrm{O}_{\text {foram }}$ to $\Delta^{18} \mathrm{O}_{\mathrm{SW}}$ (Fig. 4b) with the assumption that ${ }^{18} \mathrm{O}$ enrichment in seawater during the LGM was around $1 \%$ o (Schrag et al., 1996, 2002; Bintanja and van de Wal, 2008; Shakun et al., 2015). We follow Mori et al. (2018) in defining the residual variation in $\delta^{18} \mathrm{O}_{\text {Ото2 }}$ by subtracting the influence from $\delta^{18} \mathrm{O}_{\mathrm{SW}}$ change $\left(\Delta^{18} \mathrm{O}_{\mathrm{SW}}\right)$ as follows:

$\Delta^{18} \mathrm{O}_{\text {ото2-SW }}=\delta^{18} \mathrm{O}_{\text {от02 }}-\Delta^{18} \mathrm{O}_{\mathrm{SW}}($ in VPDB scale) (2)

We then assume that residual variation $\left(\Delta^{18} \mathrm{O}_{\text {OT02-sw }}\right)$ reflects variations in air temperature (temperature dependency of isotopic fractionation) and hydrologic processes (e.g., fractionation from seawater to vapor, amount effect, and continental effect on meteoric $\delta^{18} 0$ ).

\subsection{Carbonate clumped isotope $\left(\Delta_{47}\right)$}

\subsubsection{Stalagmite $\Delta_{47}$ value}


The principle of clumped isotope thermometry is based on the temperature dependency of the observed abundance anomaly of the ${ }^{13} \mathrm{C}-{ }^{18} \mathrm{O}$ bond in carbonate relative to the stochastic abundance calculated using bulk $\delta^{13} \mathrm{C}$ and $\delta^{18} \mathrm{O}$ values. The abundance anomaly of ${ }^{13} \mathrm{C}^{18} \mathrm{O}^{16} \mathrm{O}\left(\Delta_{47}\right)$ in $\mathrm{CO}_{2}$ from acid digestion of carbonate minerals is negatively correlated with the temperature of carbonate precipitation (Ghosh et al., 2006; Schauble et al., 2006). The analysis of carbonates synthesized at known temperatures provides an experimental (empirical) calibration between temperature and $\Delta_{47}$ (e.g., Ghosh et al., 2006; Dennis and Schrag, 2010; Zaarur et al., 2013; Fernandez et al., 2014; Tang et al., 2014; Defliese et al., 2015; Kluge et al., 2015; Bonifacie et al., 2017; Kelson et al., 2017; Kato et al., 2019). Nevertheless, estimating paleotemperature from stalagmite $\Delta_{47}$ values is challenging. $\mathrm{CO}_{2}$ degassing from cave water leads to isotopic disequilibrium in the dissolved inorganic carbon (DIC) pool and thus a smaller $\Delta_{47}$ value of carbonate, which yields higher temperatures than predicted (e.g., Guo and Zhou., 2019). KIEs under these conditions have been reported from natural and laboratory speleothem $\Delta_{47}$ results (Affek et al., 2008, 2014; Daëron et al., 2011; Kluge and Affek, 2012; Affek, 2013; Affek and Zaarur, 2014; Kato et al., 2021).

Our previous study (Kato et al., 2019) measured the $\Delta_{47}$ values of two sample sets: 1 ) calcites synthesized at different temperatures $\left(2.9^{\circ} \mathrm{C}-61.0^{\circ} \mathrm{C}\right)$ and 2$)$ Japanese natural tufa collected at monthly intervals, for which the precipitation temperature was carefully estimated $\left(5.6^{\circ} \mathrm{C}-16.0^{\circ} \mathrm{C}\right)$. Synthetic calcites were precipitated according to the "mixed-solution method" to minimize the kinetic effect of $\mathrm{CO}_{2}$ degassing by bulk solution, and tufa samples were collected monthly at two sites by Kawai et al. (2006). Similar to stalagmite settings, $\mathrm{CO}_{2}$ degassing induces calcite precipitation in tufa by increasing its saturation state in stream water (Ford and Pedley, 1996; Kano et al., 2003, 2019; Kawai et al., 2006). We found a clear difference in the $\Delta_{47}$ values of synthetic calcites and tufa samples. The $\Delta_{47}$ values of tufa were lower than those of synthetic calcites, which is in the same direction as reported in the stalagmite studies referred above (Kato et al., 2019). According to our results, the range of the $\Delta_{47}$ offset between the tufa samples and synthetic calcite appears stable throughout the year, within a temperature range of $5.6^{\circ} \mathrm{C}-16.0^{\circ} \mathrm{C}$ and a $p \mathrm{CO}_{2}$ of $0.55-1.01 \mathrm{matm}$ (Kato et al., 2019). Since these factors (temperature and $p \mathrm{CO}_{2}$ ) control the rate of $\mathrm{CO}_{2}$ degassing, our observations indicate that the degassing rate does not significantly influence the kinetic effect on the $\Delta_{47}$ offset (Kato et al., 2019). Besides that for the synthetic calcite, Kato et al. (2019) developed an empirical temperature calibration for the natural tufa samples (Eq. 3) as follows:

$\Delta_{47}=(0.0336 \pm 0.0036) * 10^{6} / T^{2}+(0.301 \pm 0.048)(3)$

where $\mathrm{T}$ is absolute temperatures in Kelvins. The evaluated temperature offset between the two calibrations was $\sim 4^{\circ} \mathrm{C}$ (Kato et al., 2019), which broadly corresponds to the temperature offset from equilibrium conditions observed in modern-day speleothems, such as Soreq Cave, Israel (Affek et al., 2014). The $\Delta_{47}$ temperature calibration of tufa (Eq. 3; Kato et al., 2019) was applied to the $\Delta_{47}$ values of Hiro-1 stalagmite and successfully yielded the paleotemperature (Kato et al., 2021). We therefore applied the same calibration (Eq. 3) to stalagmite $\Delta_{47}$ to estimate paleotemperature in this study. 


\subsection{2 $\Delta_{47}$ measurement and calculation}

We collected subsamples for carbonate clumped isotope $\left(\Delta_{47}\right)$ measurement from 68 layers throughout OT02. To avoid strong disequilibrium effects as much as possible, subsamples were collected from clear layers excluding opaque and muddy horizons presumed to have formed under depressed and/or discontinuous calcite precipitation. The significantly large prior calcite precipitation (PCP) associated with dry conditions in Maboroshi Cave likely caused smaller $\Delta_{63}$ of drip water DIC and smaller $\Delta_{47}$ of Hiro-1 stalagmite (Kato et al., 2021).

$\Delta_{47}$ measurements were performed using a dual inlet mass spectrometer (Finnigan MAT-253) at Kyushu University for four discrete periods from 2018 to 2019. Each subsample was measured once or twice, and the stability of $\Delta_{47}$ measurements was confirmed by repeated measurements of an in-house calcite standard (Hiroshima standard; $\delta^{13} \mathrm{C}=-0.47 \%$ o, $\delta^{18} \mathrm{O}=-5.04 \%$ o and $\Delta_{47}=0.671 \%$ o), which yielded $1 \mathrm{SD}$ of $\pm 0.006 \%$ o $-0.009 \%$ o ( $n=5-13$ for each period of measurement) corresponding to $\pm 1.8^{\circ} \mathrm{C}-3.7^{\circ} \mathrm{C}$ in the temperature range of OT02. Five milligrams of powdered carbonate were digested by phosphoric acid at $90^{\circ} \mathrm{C}$ for $\sim 5 \mathrm{~min}$ and the generated gas was immediately trapped by a stainless-steel tube cooled by liquid nitrogen. Moisture was separated from $\mathrm{CO}_{2}$ gas using a liquid nitrogen and ethanol slush, after which $\mathrm{CO}_{2}$ was introduced to a 30-m-long capillary column (Supel-Q PLOT) with a helium carrier gas. The column was cooled to $-10^{\circ} \mathrm{C}$ to remove organic contaminants. Purified $\mathrm{CO}_{2}$ was analyzed by MAT-253 configured for measurements of masses 44-49 with pressure adjustment to produce an $\mathrm{m} / \mathrm{z} 44$ signal of $16 \mathrm{~V}$. The integration time was $30 \mathrm{~s}$. We applied the Pressure Baseline correction of He et al. (2012) with the off-peak measurement of the background intensities of masses 45-49. Each analysis comprised 5-8 acquisitions, with 4.5 off-peak (nine alternate detections; five times for the reference side and four times for the sample side), 8 on-peak, and 4 off-peak cycles per acquisition.

Further data processing to obtain $\Delta_{47}$ values was performed using Microsoft Excel spreadsheets that first provided $\Delta_{47}$ value versus working gas (Oztech; $\delta^{13} \mathrm{C}=-3.61 \%$ o VPDB, and $\delta^{18} \mathrm{O}=24.90 \%$ o VSMOW). We applied the ${ }^{17} \mathrm{O}$ correction of Brand et al. (2010) (with $\mathrm{K}=0.01022461, \lambda=0.528$ ) to calculate $\Delta_{47}$ values. Each $\Delta_{47}$ value was adjusted on the absolute reference frame of Dennis et al. (2011) and expressed as $\Delta_{47-A R F}$. Raw $\Delta_{47 \text {-[EGvsWG] }}$ was 1$)$ corrected using the $\delta^{47}$-dependence slope $\left(-0.000064 \%\right.$ in $\Delta_{47}$ per $1 \%$ o of $\delta^{47}$; Kato et al., 2019), 2) converted to $\Delta_{47-\mathrm{RF}}$ using an empirical transfer function, and 3) converted to $\Delta_{47-A R F}$ by adding the acid fractionation factor of Defliese et al. (2015). We describe $\Delta_{47-A R F}$ simply as $\Delta_{47}$ unless otherwise noted.

\subsection{Paleometeoric $\delta^{18} 0$ reconstruction}

As mentioned above, stalagmite $\delta^{18} \mathrm{O}_{\mathrm{C}}$ value is controlled by the temperature of calcite formation and the $\delta^{18} \mathrm{O}_{\mathrm{W}}$ value of water. Using the paleotemperature determined by carbonate clumped isotope and the temperature dependency of isotopic fractionation between calcite and water, past $\delta^{18} O_{W}$ values can be 
calculated from the calcite $\delta^{18} \mathrm{O}_{\mathrm{C}}$ value. We applied the temperature dependency of $\delta^{18} \mathrm{O}$ of Tremaine et al. (2011; Eq. 4) as follows:

$1000 \ln a_{\text {water-calcite }}=16.1\left(10^{3} T^{-1}\right)-24.6(4)$

Eq. 4 was established for cave deposits (Tremaine et al., 2011) and is also consistent with $\delta^{18} \mathrm{O}$ variability in Japanese stalagmites studied by Mori et al. (2018) and Kato et al. (2021).

For the present study, we defined two types of the index of past meteoric isotopes, $\delta^{18} \mathrm{O}_{\mathrm{MW}}$ and

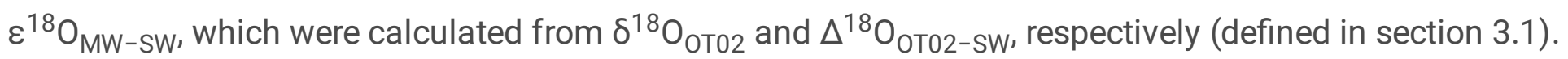
$\delta^{18} \mathrm{O}_{\mathrm{MW}}$ principally refers to cave drip water, which is assumed to be almost the average value of meteoric water $\delta^{18} \mathrm{O} . \varepsilon^{18} \mathrm{O}_{\mathrm{MW} \text {-SW }}$ refers to the difference between $\delta^{18} \mathrm{O}_{\mathrm{MW}}$ and $\delta^{18} \mathrm{O}_{\mathrm{SW}}$; in other words, the total fractionation in the hydrologic circulation process (from seawater to meteoric water) involving changes in climatic factors including the monsoon intensity, moisture trajectory, and the seasonality of precipitation.

\section{Results}

\subsection{Oxygen isotopes}

The $\delta^{18} \mathrm{O}_{\text {Ото2 }}$ (VPDB) values presented by Mori et al. (2018) vary between $-8.2 \%$ o and $-6.3 \%$ (Fig. $4 \mathrm{a}$ ). At $63.5-34.8 \mathrm{ka}$, the $\delta^{18} \mathrm{O}_{\text {Ото2 }}$ generally becomes less negative from older to the younger layers and displays four millennial-scale events with an amplitude of $0.5 \%{ }^{-}-1 \%$, which likely correspond to Heinrich events. The $\delta^{18} \mathrm{O}_{\text {Ото2 }}$ values of the Holocene interval (8.8-2.6 ka) mostly fall between $-7 \%$ o and $-8 \%$; however, a slight negative shift of $\sim 0.5 \%$ is observed around $6 \mathrm{ka}$ (Fig. $4 \mathrm{a}$ ). As suggested by Mori et al. (2018), the overall trend of $\delta^{18} \mathrm{O}_{\text {Ото2 }}$ follows that of seawater $\delta^{18} \mathrm{O}$ (Fig. $4 \mathrm{~b}$ ).

$\Delta^{18} \mathrm{O}_{\text {Ото2-Sw }}$ shows a smaller variation between $-8.3 \%$ and $-6.7 \%$ o. Most values fall between $-7 \%$ ond $-8 \%$ o (Fig. 4C). Although no significant difference was observed between the averaged $\Delta^{18} \mathrm{O}_{\text {OT02-sW }}$ values of the latest Pleistocene $(63.5-34.8 \mathrm{ka})$ and the Holocene $(8.8-2.6 \mathrm{ka})$, the $\Delta^{18} \mathrm{O}_{\text {Oто2-sw }}$ show a very slight increasing trend from the lower to the upper portions.

\subsection{Carbonate clumped isotope $\left(\Delta_{47}\right)$}

The $\Delta_{47}$ values of 68 layers in OT02 range from $0.670 \%$ o to $0.747 \%$ o (Fig. $4 \mathrm{~d}$ ), corresponding to $1.4^{\circ} \mathrm{C}-$ $28.6^{\circ} \mathrm{C}$ using the equation 3 (Table 1). The overall trend of $\Delta_{47}$ variations broadly agrees with trends of

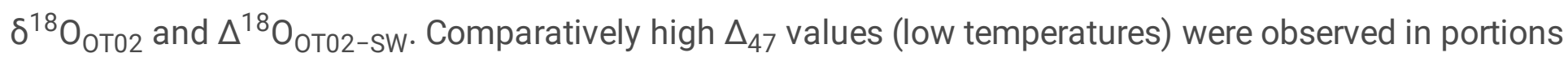
in which less negative $\delta^{18} \mathrm{O}_{\text {Ото2 }}$ and $\Delta^{18} \mathrm{O}_{\text {Ото2-sw }}$ values were observed.

The average $\Delta_{47}$ temperature of the Holocene portion $\left(16.3^{\circ} \mathrm{C}, 8.8-2.6 \mathrm{ka}\right)$ is $6.6^{\circ} \mathrm{C}$ higher than the average of the lower portion $\left(9.7^{\circ} \mathrm{C}, 63.5-34.8 \mathrm{ka}\right)$. The observed temperature drops corresponding to the 
Heinrich cooling events are $3^{\circ} \mathrm{C}-5^{\circ} \mathrm{C}$.

\section{$4.3 \delta^{18} O_{M W}$ and $\varepsilon^{18} O_{M W-s W}$}

$\delta^{18} \mathrm{O}_{\mathrm{MW}}$ and $\varepsilon^{18} \mathrm{O}_{\mathrm{MW}-\mathrm{SW}}$ values vary between $-10.3 \%$ and $-6.2 \%$ ond $-11.0 \%$ and $-6.2 \%$, respectively (Table 1). Variations in $\delta^{18} \mathrm{O}_{\mathrm{MW}}$ show a flatter trend than those of $\delta^{18} \mathrm{O}_{\text {Oто2 }}$ and $\Delta^{18} \mathrm{O}_{\text {Oто2-sW. The }}$ averaged $\delta^{18} \mathrm{O}_{\mathrm{MW}}$ and $\varepsilon^{18} \mathrm{O}_{\mathrm{MW} \text {-SW }}$ values of the Holocene (8.8-2.6 ka) portion are less negative than those of the latest Pleistocene $(63.5-34.8 \mathrm{ka})$ portion, as is the crosscurrent of $\delta^{18} \mathrm{O}_{\mathrm{OTO2}}$ and

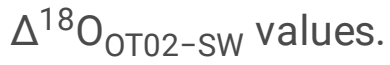

\section{Discussion}

\subsection{Discrimination of temperature and KIEs}

Before paleoclimatic reconstruction, we inspected the reliability of our results as paleoclimatic records. In principle, both calcite $\delta^{18} \mathrm{O}$ and $\Delta_{47}$ values depend on temperature; nevertheless, this temperature dependency can be complicated by the $\mathrm{KIE}$ due to $\mathrm{CO}_{2}$ degassing from the parent water. It has been suggested that $\mathrm{CO}_{2}$ degassing elevates $\delta^{18} \mathrm{O}$ values and lowers $\Delta_{47}$ values of carbonate minerals by incomplete isotopic exchange among water and DIC species (Guo, 2008; Daëron et al., 2011; Kluge and Affek, 2012; Guo and Zhou, 2019) and can generate isotopic offsets (differences between actual and equilibrium values). Some speleothems show a negative correlation between $\delta^{18} \mathrm{O}$ offset and $\Delta_{47}$ offset due to the KIE (Daëron et al., 2011; Wainer et al., 2011; Kluge and Affek, 2012; Kluge et al., 2013; Affek et al., 2014). This type of covariation (negative correlation) between $\delta^{18} \mathrm{O}$ and $\Delta_{47}$ offsets develops when KIE fractionation significantly affects $\delta^{18} \mathrm{O}$ and $\Delta_{47}$. In such cases, $\Delta_{47}$ temperature is unusable for paleoclimatic reconstruction.

Kato et al. (2021) examined the covariation between $\Delta^{18} \mathrm{O}_{\text {Hiro-1-sw }}$ and $\Delta_{47}$ values of the Hiro-1 stalagmite, which were calculated using the same method as in the present study, to distinguish the influence from KIE. The positive covariation expected for equilibrium conditions was found in most parts of the Hiro-1 stalagmite, supporting the interpretation that both $\Delta_{47}$ and $\delta^{18} \mathrm{O}_{\mathrm{Hiro-1}}$ changed mainly as a function of temperature. Several layers of low growth rate and high $\delta^{13} \mathrm{C}$ in Hiro-1 which imply dry conditions and high PCP (Hori et al., 2013), however exhibited features of the strong influence of KIE disequilibrium: less negative $\delta^{18} \mathrm{O}$ values and small $\Delta_{47}$ values. In these layers of the Hiro-1 stalagmite, according to our estimate (Kato et al., 2021), significantly large PCP likely caused small $\Delta_{63}$ of DIC and small stalagmite $\Delta_{47}$, and the KIE was likely further induced by rapid supersaturation and precipitation in the evaporating water film, in which both $\delta^{18} \mathrm{O}$ and $\delta^{13} \mathrm{C}$ increased.

In the 0T02 stalagmite, a weak but positive covariation between $\Delta^{18} \mathrm{O}_{\text {OT02-sw }}$ and $\Delta_{47}$ values was noted throughout (Fig. $5 a, r=0.36, n=78$ ). This supports the interpretation that temperature change is the 
principal factor controlling both $\Delta_{47}$ and $\Delta^{18} \mathrm{O}_{\text {OT02-SW }}$ and that the signals $\left(\Delta_{47}, \delta^{18} \mathrm{O}_{\text {Ото2 }}\right.$, and $\Delta^{18} \mathrm{O}_{\text {От02-SW) }}$ ) seem not to be disturbed by strong KIE disequilibrium. The growth rate of the OT02 stalagmite is higher and more stable than that of the Hiro-1 stalagmite. Additionally, subsamples for $\Delta_{47}$ measurements were collected from clear layers of OT02 excluding opaque/muddy horizons to avoid the effect of KIE as much as possible, as mentioned in section 3.2.2.

\subsection{Features in the correlation between $\Delta_{47}$ vs $\Delta^{18} \mathrm{O}_{\text {от02-SW }}$}

The relationship between the two temperature-controlled factors $\left(\Delta_{47}\right.$ and $\left.\delta{ }^{18} \mathrm{O}_{\mathrm{C}}\right)$ is not simple. In the case of the Hiro-1 stalagmite, different regressions of $\Delta_{47}$ versus $\Delta^{18} \mathrm{O}_{\text {Hiro-1-sw }}$ were obtained from three discrete periods, 18.0-16.0, 14.2-12.6, and 7.7-4.9 ka (Fig. 5a, Kato et al., 2021). A especially large difference was noted between regressions in the pre-Holocene and mid-Holocene. Kato et al. (2021) explained this discrepancy in regressions by differences in meteoric water $\delta^{18} O_{M W}\left(\varepsilon^{18} O_{M W-s W}\right)$ due to the presence or absence of the SIS (Fig. 1b), which is an important vapor source for Maboroshi Cave in Hiroshima. The SIS is currently shallow (mostly $<50 \mathrm{~m}$ deep) and was almost exposed during the glacial sea-level low. Because of the absence of this inland sea, moisture was predominantly transported over longer distances from the marine vapor source. Less negative $\delta^{18} \mathrm{O}_{\mathrm{MW}}$ from the SIS was established by the Holocene glacial retreat (Kato et al., 2021). By contrast, the influence of the SIS is negligible for Ohtaki Cave in Gifu prefecture (Fig. 1b). This is likely the reason for the unified regression between $\Delta_{47}$ and $\Delta^{18} \mathrm{O}_{\text {OT02-Sw }}$ for Ohtaki Cave (Fig. 5a).

Comparing to Hiro-1 values, another characteristic in the regression of OT02 $\Delta_{47}$ vs $\Delta^{18} \mathrm{O}_{\text {OT02-sW }}$ becomes apparent (Fig. 5a), which is expressed as follows:

$\Delta^{18} \mathrm{O}_{\text {Oт02-SW }}=5.05 \Delta_{47}-11.15$ (Eq. $\left.5 ; \mathrm{n}=78, \mathrm{R}^{2}=0.132\right)$

With a slope of 5.05 , this is clearly shallower than that of the Hiro- 1 stalagmite, for which the corresponding value is approximately 40 (37.71-44.15; Kato et al., 2021; Fig. 5a). Where both stalagmite $\delta^{18} \mathrm{O}_{\mathrm{C}}$ and $\Delta_{47}$ are solely controlled by depositional temperature (in other words, assuming a constant drip water $\delta^{18} \mathrm{O}_{\mathrm{W}}$ ), the relationship between $\delta^{18} \mathrm{O}_{\mathrm{C}}$ and $\Delta_{47}$ can be theoretically calculated. We applied the temperature dependency of $\Delta_{47}$ (Eq. 3) and $\delta^{18} \mathrm{O}$ (Eq. 4; Tremaine et al., 2011). The theoretical relationship between $\Delta_{47}$ and $\Delta^{18} \mathrm{O}_{\text {stalagmtie-sw }}$ is almost linear, with a slope around 70 , but is slightly dependent on the $\Delta_{47}$ value (i.e., temperature) (72.5 at $\Delta_{47}=0.69,68.5$ at $\left.\Delta_{47}=0.74\right)$.

For Hiro-1, Kato et al. (2021) interpreted that a possible process for the shallower slopes was the temperature dependency of meteoric water $\delta^{18} \mathrm{O}_{\mathrm{MW}}$; thus, ${ }^{18} \mathrm{O}$ depletion during vapor generation decreases with increasing temperature (e.g., Horita and Wesolowski, 1994; Clark and Fritz, 1997). To evaluate this interpretation, Kato et al. (2021) defined the temperature-dependent fraction from seawater 
to meteoric water as $\mathrm{FT}_{\mathrm{SW}-\mathrm{MW}}$ (in \%o) and expressed the relationships between $\Delta_{47}$ and $\Delta^{18} \mathrm{O}_{\mathrm{C}}$ (Hiro-1 or от02)-sw as shown in Eqs. 6 and 7:

$f\left(\Delta_{47}\right)=\mathrm{A} \Delta_{47}+\mathrm{B}=\Delta^{18} \mathrm{O}_{\mathrm{C}}$ (Hiro-1 or Ото2)-SW $-\mathrm{FT}_{\mathrm{SW}-\mathrm{MW}}(6)$

$d \mathrm{FT}_{\mathrm{SW}-\mathrm{MW}} / d \mathrm{~T}=-a \mathrm{FT}_{\mathrm{SW}-\mathrm{MW}}=-a \mathrm{~T}+b(7)$

where $\mathrm{T}$ is the temperature in ${ }^{\circ} \mathrm{C}$ and $\mathrm{FT}_{\mathrm{SW}-\mathrm{MW}}$ is assumed to be a linear function of temperature. The temperature-dependent coefficient of $\mathrm{FT}_{\mathrm{SW}-\mathrm{MW}}$ is expressed by $a\left(\% /{ }^{\circ} \mathrm{C}\right)$. The slope $\mathrm{A}$ in Eq. 6 increases

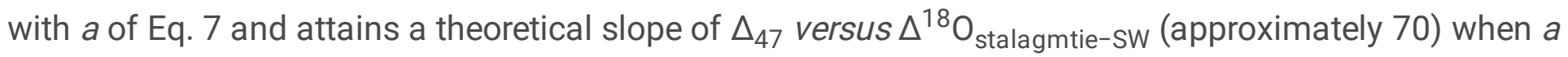
takes an appropriate value.

In the Hiro- 1 stalagmite, slope A in Eq. 6 attains the theoretical slope when $a$ is at $0.077 \%{ }^{\circ}-0.098 \% \circ /{ }^{\circ} \mathrm{C}$ (black lines in Fig. 5b; Kato et al., 2021). The range of $a_{\text {Hiro-1 }}$ is comparable with the temperature dependency of ${ }^{18} \mathrm{O}$ fractionation between water and vapor, which is $0.094 \%{ }^{\circ}-0.102 \% \circ /{ }^{\circ} \mathrm{C}$ at $10^{\circ} \mathrm{C}$, $0.085 \%{ }^{\circ}-0.090 \%{ }^{\circ} /{ }^{\circ} \mathrm{C}$ at $20^{\circ} \mathrm{C}$, and $0.076 \%{ }^{\circ}-0.079 \% \circ /{ }^{\circ} \mathrm{C}$ at $30{ }^{\circ} \mathrm{C}$ (Horita and Wesolowski, 1994 ; Clark and Fritz, 1997). Figure $5 \mathrm{~b}$ also shows the calculation results for the ОT02 stalagmite (red line for the Holocene and blue line for latest Pleistocene). Slope A attains the theoretical slope (approximately 70) when $a_{0 \text { Тт02 }}$ is at $0.18 \% /{ }^{\circ} \mathrm{C}$ for both the Holocene and latest Pleistocene, which is clearly larger than $a_{\text {Hiro-1. }}$.

\subsection{Reason for the larger temperature-dependent coefficient of $\mathrm{FT}_{\text {SW-MW }}($ a) in OT02}

We assume that the divergence in a values for OT02 and Hiro-1 are ascribed to regional differences in precipitation characteristics. As described in section 2.2, in both Nagataki (near Ohtaki Cave; Fig. 2c) and Yuki (near Maboroshi Cave; Fig. 2d), less negative $\delta^{18} \mathrm{O}_{\mathrm{MW}}$ values are observed during the warm season, whereas more negative $\delta^{18} \mathrm{O}_{\mathrm{MW}}$ values are observed in the cold season. However, in Nagataki, winter precipitation accounts for a larger proportion of the annual total, and the yearly variation of winter precipitation is far larger than in Yuki (Fig. 2a and b). Hence, the amount ratio of winter/annual precipitations is an important factor influencing the annual average $\delta^{18} \mathrm{O}_{M W}$ values at Ohtaki Cave.

The major control of winter precipitation from the Japan Sea side is the strength of the EAWM. Hirose and Fukudome (2006) found a significant correlation $\left(R^{2}=0.85\right)$ between the average winter precipitation on the Japan Sea side of Honshu and Hokkaido islands in 1907-2006 and the winter monsoon index of Hanawa et al. (1988), which reflects differences in the sea-level pressures between Irkutsk and Nemuro in winter and represents the strength of the EAWM. Hirose and Fukudome (2006) also found that the Japan Sea SST in winter (November-January) exhibited a significant correlation with winter precipitation on the Japan Sea side $\left(R^{2}=0.82\right)$. This relation occurs because the high SST of the Japan Sea increases evaporation from seawater, which is the supply source of winter snow/rainfall to Japan. In the Northwest 
Pacific and East Asia, the land-sea thermal contrast is a driving force behind both the EASM and EAWM. As described above, the proportion of winter/summer precipitation is more variable in the Ohtaki region and the proportion is largely dependent on winter precipitation. Cooling of the land area results in increased winter precipitation and decreased annual average $\delta^{18} \mathrm{O}_{\mathrm{MW}}$ values in Ohtaki. This is likely the reason for the apparently larger temperature dependency of meteoric water $\delta^{18} \mathrm{O}_{\mathrm{MW}}\left(a ; \%\right.$ o $\left./{ }^{\circ} \mathrm{C}\right)$ in the Ohtaki region.

\subsection{Terrestrial paleotemperature}

We interpret temperature to be the dominant control on the 0T02 $\Delta_{47}$ record, on the basis of the discussion presented in section 5.1. The Holocene $\Delta_{47}$ temperature appears consistent with the present cave temperature of $13^{\circ} \mathrm{C}$, although the growth of OT02 was suspended in $2.6 \mathrm{ka}$ and present $\Delta_{47}$ data are absent. The $\Delta_{47}$ temperature record from OT02 (Table 1 ) is also broadly consistent with known climatic stages, such as cooling during Heinrich events, warming during the Holocene, and a warming peak around the Hypsithermal event (9 to 6-5 ka; e.g., Wanner et al., 2008; Fig. 6). In the period common to the OT02 and Hiro-1 stalagmites (7.7-4.5 ka), the two stalagmites exhibit very similar patterns in $\Delta_{47}$ temperature (Fig. 4 and 6); a rapid warming in 7.0-6.0 ka after a temporal cooling of $\sim 5^{\circ} \mathrm{C}$ at $7.0 \mathrm{ka}$ from around $15^{\circ} \mathrm{C}$ at $8.0-7.5 \mathrm{ka}$ and a gradual cooling to the cessation of stalagmite growth. Three intervals of distinct cooling by $3-5^{\circ} \mathrm{C}$ are likely correlated to Heinrich events $\mathrm{H} 6, \mathrm{H} 5.2$, and $\mathrm{H} 5$ (Fig. 6). Although the averaged $\Delta_{47}$ temperature of the latest Pleistocene portion of OT02 (63-35 ka) is lower than that of the Holocene portion, the $\Delta_{47}$ temperature in warm periods between each Heinrich event reached $10^{\circ} \mathrm{C}-$ $15^{\circ} \mathrm{C}$, which is as high as the present temperature and the average of the middle Holocene.

Our $\Delta_{47}$ temperature equation (Eq. 3) was calibrated using the $\Delta_{47}$ values of natural tufa deposited at $5.6^{\circ} \mathrm{C}-16.0^{\circ} \mathrm{C}$. The high $\Delta_{47}$ temperatures over $20^{\circ} \mathrm{C}$ around $5.4-2.9$ ka therefore somewhat deviate from the temperature range covered by Eq. 3. Because of the nature of carbonate clumped isotope thermometry, the uncertainty of $\Delta_{47}$ temperatures is greater at higher temperatures, because the $\Delta_{47}$ value exhibits an inverse proportionality to the square of the temperature in Kelvins. Even after considering these larger errors and uncertainties, the average temperature during the period from 5.4 to $3.8 \mathrm{ka}$ (considering the larger dating error for OT02 mentioned above, which likely corresponds to the warm maximum of $6.3-4.9$ ka recorded in Hiro- 1 ) is $19.9^{\circ} \mathrm{C} \pm 6.0^{\circ} \mathrm{C}$ and is clearly higher than the present cave temperature of $13^{\circ} \mathrm{C}$.

Seasonal temperature variation is currently very limited in the deeper part of Ohtaki Cave, and it is thus likely that the past cave temperature was also stable on seasonal timescales. We do not presume, however, that the high-average $\Delta_{47}$ temperature during the Hypsithermal means uniform warming of all seasons. In Nagataki (near Ohtaki Cave), the temperature variation tends to be largest in the colder season (December-April) and smaller in the warmer season (May-October; Fig. 3a). The correlation coefficient (R) of annual and monthly temperatures is large in February-May and September-October and smallest in the warmest months (July-August; Fig. 3a). Together, this indicates that summer 
temperature is not an important control in the determination of annual average temperatures. Variability in annual average temperature is largely dependent on temperature variability in spring and autumn and is also somewhat dependent on winter temperature. This indicates that the annual average temperature in Nagataki is characterized by the length of the summer (warmer interval) and the winter (colder interval). We presume that the higher cave temperature of $19.9^{\circ} \mathrm{C} \pm 6.0^{\circ} \mathrm{C}$ observed in the $5.4-3.8 \mathrm{ka}$ period of OT02 (corresponding 6.3-4.9 ka of Hiro-1) was induced by longer high summers and shorter winters than at present, accompanied by the warm climate optimum of the Hypsithermal event.

\subsection{Paleoprecipitation history}

In section 5.4, we explained changes in cave temperature arising from interactions between the summer and winter seasons. In Japan, summer and winter climates are characterized by the EASM and EAWM winds, respectively, where rainfall from EASM winds has a less negative $\delta^{18} O_{M w}$ value and rain/snowfall from EAWM winds has a more negative $\delta^{18} \mathrm{O}_{M W}$ value. Changes in summer and winter durations might therefore affect the precipitation balance from EASM and EAWM winds and the annual average of $\delta^{18} \mathrm{O}_{\mathrm{MW}}$ value. Based on this assumption, paleometeoric water should have a more negative $\delta^{18} \mathrm{O}_{\mathrm{MW}}$ value in colder periods and a less negative $\delta^{18} \mathrm{O}_{\mathrm{MW}}$ value in warmer periods. However, the relation between EASM and EAWM is not simple. Previous paleoclimatic studies have indicated numerous relationships between the intensities of EASM and EAWM: an inverse correlation (Xiao et al., 1995; Yancheva et al., 2007; Liu et al., 2009), a positive correlation (Zhang and Lu, 2007), and both positive and inverse correlations depending on the period and timescale concerned (Steinke et al., 2011; Ge et al., 2017). Recently, Yan et al. (2020) presented simulation results to investigate the relationship between time series changes in EASM and EAWM, showing that their intensities are positively correlated at orbital timescale due to seasonal insolation forcing but are negatively correlated over multidecadal to millennial timescales, primarily as a result of internal variability in the Atlantic Meridional Overturning Circulation and its subsequent teleconnection to East Asia via land-sea thermal contrasts.

Focusing on climatic changes at the centennial-millennial timescale, i.e., Heinrich cooling events and Hypsithermal warming, the result of our meteoric water $\delta^{18} \mathrm{O}_{\mathrm{MW}}$ reconstruction is consistent with the assumption of a more negative (less negative) $\delta^{18} \mathrm{O}_{\mathrm{MW}}$ value in colder (warmer) periods (Fig. 6). The $\varepsilon^{18} \mathrm{O}_{\mathrm{MW} \text {-sw }}$ value (and accordingly the $\delta^{18} \mathrm{O}_{\mathrm{MW}}$ value) was more negative in colder periods such as Heinrich cooling events and the period of cooling around $7 \mathrm{ka}$ and less negative in warmer periods.

This is consistent with the assumption in section 5.4 that the longer summer durations and larger amounts of EASM rainfall caused the average $\delta^{18} \mathrm{O}_{\mathrm{MW}}$ value in the Hypsithermal warm period. By contrast, it is presumed that EAWM brought a larger amount of snow and rainfall during long winters to Ohtaki Cave during Heinrich cooling events. Very few previous studies have reported terrestrial climatic records in Heinrich events from Japan. Nakamura et al. (2013) performed stratigraphic analyses of acoustic records of sediments in Lake Nojiri, the Japan Sea side of central Japan (Fig. 1b) where winter snowfall accounts for approximately $30 \%$ of annual precipitation. They revealed lake level fluctuation 
during the past 45,000 years and found eight sets of rising and falling levels, although their results contain large dating errors of $\pm 1,000-15,000$ years. They also found that peaks of lake level corresponded to cold climate stages such as Heinrich cooling events 1-4 and the Younger Dryas. They presumed that lake level rises were caused by increased snowfall from an enhanced winter monsoon (EAWM). Light blue vertical bands in Fig. 6 indicate the periods of peak lake level in Nojiri identified by Nakamura et al. (2013). Unfortunately, the record of Nakamura et al. (2013) does not include older Heinrich events $\mathrm{H} 5-6$, for which particularly negative $\varepsilon^{18} O_{M W-s w}$ values were reconstructed from OT02 (Fig. 6). However, the durations of high lake level periods in Nojiri seem to correspond to the periods of colder temperature and more negative $\varepsilon^{18} \mathrm{O}_{\mathrm{MW} \text {-sw }}$ values. Increased precipitation from EAWM was likely also bought into the Ohtaki region and caused a decrease in the annual average of $\varepsilon^{18} O_{M W-S W}$ during these cold stages.

As described here, changes in the amount ratio of summer and winter precipitations from EASM and EAWM caused the divergence in $\varepsilon^{18} \mathrm{O}_{\mathrm{MW} \text {-sw }}$ values in the Ohtaki region, although the temperature dependency of the fractionation between seawater and meteoric water (as discussed in section 5.3) also accounts for the relationship between temperature and $\varepsilon^{18} O_{M W-S W}$.

As described in section 2.2, precipitation from EAWM is minor in the region of Maboroshi Cave. We suggest that a strong EAWM and weak EASM during cold periods caused the dry conditions of Maboroshi Cave, which might have resulted in the interruptions of the growth of Hiro-1 and KIE disturbance of Hiro-1 records (Fig. 6).

\section{Summary}

We analyzed carbonate clumped isotopes $\left(\Delta_{47}\right)$ of the 0T02 stalagmite from Ohtaki Cave for the age intervals of $2.6-8.8$ and $34.8-63.5 \mathrm{ka}$ and revealed changes in terrestrial temperature and meteoric $\delta^{18} \mathrm{O}$. The average $\Delta_{47}$ temperature of the Holocene portion $\left(16.3^{\circ} \mathrm{C}, 8.8-2.6 \mathrm{ka}\right)$ is $6.6^{\circ} \mathrm{C}$ higher than that of the latest Pleistocene portion $\left(9.7^{\circ} \mathrm{C}, 63.5-34.8 \mathrm{ka}\right)$. Reductions in $\Delta_{47}$ temperature correspond to Heinrich cooling events and are approximately $3^{\circ} \mathrm{C}-5^{\circ} \mathrm{C}$. We presume that higher cave temperatures of $19.9^{\circ} \mathrm{C} \pm 6.0^{\circ} \mathrm{C}$ observed during the middle Holocene (5.4-3.8 $\mathrm{ka}$ of OT02) were induced by longer high summers and shorter winters than at present, accompanied by the Hypsithermal warm climate optimum.

We also reconstructed two indices of meteoric oxygen isotopes, $\delta^{18} O_{M W}$ and $\varepsilon^{18} O_{M W-s w}$, by subtracting the temperature effect from $\delta^{18} \mathrm{O}_{\mathrm{OTO2}}$ and $\Delta^{18} \mathrm{O}_{\mathrm{OTO2}-\mathrm{SW}}$. The averaged $\delta^{18} \mathrm{O}_{\mathrm{MW}}$ and $\varepsilon^{18} \mathrm{O}_{\mathrm{MW} \text {-sw values }}$ through the Holocene (8.8-2.6 ka) portion are less negative than those of the latest Pleistocene (63.5$34.8 \mathrm{ka}$ ) portion. Focusing on climatic changes at centennial-millennial timescale, $\varepsilon^{18} \mathrm{O}_{\mathrm{MW} \text {-sw }}$ values (and accordingly $\delta^{18} \mathrm{O}_{\mathrm{MW}}$ values) were more negative in colder periods, such as Heinrich cooling events and the cooling event around $7 \mathrm{ka}$, and less negative in warmer periods such as the Hypsithermal. These relationships indicate the co-evolution of terrestrial paleotemperature and paleoprecipitation. In Japan, 
summer and winter climates are characterized by EASM and EAWM winds, respectively. Rainfall from EASM winds has less negative $\delta^{18} \mathrm{O}_{\mathrm{MW}}$ values and rain/snowfall from EAWM winds has more negative $\delta^{18} \mathrm{O}_{\mathrm{MW}}$ values. Increased precipitation brought by EASM has likely increased the average $\delta^{18} \mathrm{O}_{\mathrm{MW}}$ in warmer periods such as the Hypsithermal, whereas increased precipitation brought by EAWM has decreased the averaged $\delta^{18} \mathrm{O}_{\mathrm{MW}}$ in colder periods such as Heinrich cooling events.

Hence, we revealed a trend of more/less negative meteoric water $\delta^{18} \mathrm{O}_{\mathrm{MW}}$ in warmer/colder climate stages. This trend is the opposite of that assumed in conventional paleoclimate studies using Japanese stalagmites, which suggest that meteoric $\delta^{18} \mathrm{O}_{M W}$ becomes more/less negative in warm-humid/cold-dry climates due to the "amount effect." Our results also do not follow previous interpretations that variation in meteoric $\delta^{18} \mathrm{O}_{\mathrm{MW}}$ values is the dominant controlling factor of stalagmite $\delta^{18} \mathrm{O}$ value. In our study regions, major factors determining the average $\delta^{18} \mathrm{O}_{\mathrm{MW}}$ value are 1 ) the proportion between summer and winter precipitation and 2) the temperature dependency of the fractionation from seawater to meteoric water. Additionally, 3) seawater $\delta^{18} \mathrm{O}_{\mathrm{SW}}$ change $\left(\Delta^{18} \mathrm{O}_{\mathrm{SW}}\right)$ at orbital scales also influences $\delta^{18} \mathrm{O}_{\mathrm{MW}}$. These effects occur due to the hydrological setting in Japan in which moisture is brought from surrounding seas. Factor 1 is related to climatic stages on centennial scales, which is also deeply related to terrestrial temperature. Besides these three factors controlling $\left.\delta^{18} \mathrm{O}_{M W}, 4\right)$ temperature-dependent fractionation at the time of stalagmite deposition ( $\mathrm{FT}_{\text {water-stalagmite}}$ ) is an important control on stalagmite $\delta^{18} \mathrm{O}_{\mathrm{C}}$. These temperature effects on $\delta^{18} \mathrm{O}_{\mathrm{MW}}$ and $\delta^{18} \mathrm{O}_{\mathrm{C}}$ are, however, in opposite directions and the negative influence of temperature on $\delta^{18} \mathrm{O}_{\mathrm{C}}\left(\mathrm{FT}_{\text {water-stalagmite }}\right)$ exceeds the information available for past $\delta^{18} \mathrm{O}_{\mathrm{MW}}$. This explains the small amplitude of $\delta^{18} \mathrm{O}$ change in Japanese stalagmites (Mori et al., 2018; Kato et al., 2021) and has complicated the interpretation of stalagmite $\delta^{18} \mathrm{O}_{\mathrm{C}}$ records using only conventional methods of stalagmite climatology depending only on $\delta^{18} \mathrm{O}$ analysis.

\section{Declarations}

\section{Availability of data and material}

Table 1 contains all data presented in this study.

\section{Competing interests}

The authors declare that they have no competing interest.

\section{Funding}

This study was supported by Grants-in-Aid from the Japan Society for the Promotion of Science [70782019, 20J00843 and 21K18393 for HK, and 16H02235 and 20H00191 for AK] and partially supported by grants from the Science Vanguard Research Program of the Ministry of Science and Technology (MOST) (110-2123-M-002-009), the National Taiwan University (109L8926 to C.-C.S.), the 
Higher Education Sprout Project of the Ministry of Education (110L901001 and 110L8907) Taiwan ROC for C.-C.S..

\section{Authors' contributions}

HK proposed the topic, conceived and designed the study. HK, TM, AK, CCW, and CCS carried out the experimental work. HK and AK wrote the manuscript of this study. AK and CCS supervised the study. The authors read and approved the final manuscript.

\section{Acknowledgment}

Weather data and bathymetric data in this study are from the Japan Meteorological Agency (http://www.jma.go.jp) and the NOAA National Geophysical Data Center, 2009: ETOPO1 1 Arc-Minute Global Relief Model (Accessed in July 2021). We thank Yoshihiro Kuwahara and Ryoko Senda (Kyushu University) for supporting the $\Delta_{47}$ analysis.

\section{References}

Affek H. P. (2013) Clumped isotopic equilibrium and the rate of isotope exchange between $\mathrm{CO}_{2}$ and water. Amer. Jour. Sci. 313, 309-325.

Affek H. P., Bar-Matthews M., Ayalon A., Matthews A., Eiler J. M. (2008) Glacial/interglacial temperature variations in Soreq cave speleothems as recorded by "clumped isotope" thermometry. Geochim. Cosmochim. Acta 72, 5351-5360.

Affek H. P., Matthews A., Ayalon A., Bar-Matthews M., Burstyn Y., Zaarur S., Zilberman T. (2014) Accounting for kinetic isotope effects in Soreq Cave (Israel) speleothems. Geochim. Cosmochim. Acta 143, 303-318.

Affek H. P., Zaarur S. (2014) Kinetic isotope effect in $\mathrm{CO}_{2}$ degassing: insight from clumped and oxygen isotopes in laboratory precipitation experiments. Geochim. Cosmochim. Acta 143, 319-330.

Asai K., Tsujimura M., Fantong W. Y. (2014) Temporal variation of stable isotope ratios in precipitation on Chubu-mountainous areas: a case study of Mt. Ontake, Japan (in Japanese). Journal of Japanese Association of Hydrological Sciences 44, 67-77.

Bintanja R. and van de Wal R. S. W. (2008) North American ice-sheet dynamics and the onset of 100,000year glacial cycles. Nature 454, 869-872.

Bonifacie M., Calmels D., Eiler J. M., Horita J., Chaduteau C., Vasconcelos C., Agrinter P., Katz A., Passey B. H., Ferry J. M., Bourrand J.-J. (2017) Calibration of the dolomite clumped isotope thermometer from 25 to $350{ }^{\circ} \mathrm{C}$, and implications for a universal calibration for all ( $\left.\mathrm{Ca}, \mathrm{Mg}, \mathrm{Fe}\right) \mathrm{CO}_{3}$ carbonates. Geochim.

Cosmochim. Acta 200, 255-279. 
Brand W. A., Assonov S. S., Coplen T. B. (2010) Correction for the ${ }^{17} O$ interference in $\delta\left({ }^{13} \mathrm{C}\right)$ measurements when analyzing $\mathrm{CO}_{2}$ with stable isotope mass spectrometry (IUPAC Technical Report). Pure Appl. Chem. $82,1719-1733$.

Clark I., Fritz P. (1997) Environmental Isotopes in Hydrology. Lewis Publishers, New York.

Daëron M., Guo W., Eiler J., Genty D., Blamart D., Boch R., Drysdale R., Maire R., Wainer K., Zanchetta G. (2011) ${ }^{13} \mathrm{C}^{18} \mathrm{O}$ clumping in speleothems: observations from natural caves and precipitation experiments. Geochim. Cosmochim. Acta 75, 3303-3317.

Defliese W. F., Hren M. T., Lohmann K. C. (2015) Compositional and temperature effects of phosphoric acid fractionation on $\Delta_{47}$ analysis and implications for discrepant calibrations. Chem. Geol. 396, 51-60.

Dennis K. J., Affek H. P., Passey B. H., Schrag D. P., Eiler J. M. (2011) Defining an absolute reference frame for "clumped" isotope studies of $\mathrm{CO}_{2}$. Geochim. Cosmochim. Acta 75, 7117-7131.

Dennis K. J., Schrag D. P. (2010) Clumped isotope thermometry of carbonatites as an indicator of diagenetic alteration. Geochim. Cosmochim. Acta 74, 4110-4122.

Eiler J. M. (2007) "Clumped-isotope" geochemistry-The study of naturally-occurring, multiply-substituted isotopologues. Earth Planet. Sci. Lett. 262, 309-327.

Fernandez A., Tang J., Rosenheim B. E. (2014) Siderite "clumped" isotope thermometry: a new paleoclimate proxy for humid continental environments. Geochim. Cosmochim. Acta 126, 411-421.

Ford T. D., Pedley H. M. (1996) A review of tufa and travertine deposits of the world. Earth-Sci. Rev. 41, 117-175.

Fukui T. (Ed.) (1977) The Climate of Japan. Elsevier, Amsterdam.

Ge Q., Xue Z., Yao Z., Zang Z., Chu F. (2017) Anti-phase relationship between the East Asian winter monsoon and summer monsoon during the Holocene? Journal of Ocean University of China 16, 175-183.

Ghosh P., Adkins J., Affek H., Balta B., Guo W. F., Schauble E. A., Schrag D., Eiler J. M. (2006) ${ }^{13} \mathrm{C}-{ }^{18} \mathrm{O}$ bonds in carbonate minerals: a new kind of paleothermometer. Geochim. Cosmochim. Acta 70, 14391456.

Guo W. (2008) Carbonate clumped isotope thermometry: application to carbonaceous chondrites and effects of kinetic isotope fractionation. Ph. D. thesis, Caltech.

Guo W., Zhou C. (2019) Patterns and controls of disequilibrium isotope effects in speleothems: Insights from an isotope-enabled diffusion-reaction model and implications for quantitative thermometry. Geochim. Cosmochim Acta 267, 196-226. 
Hanawa K., Watanabe T., Iwasaka N., Suga T., Toba Y. (1988) Surface thermal conditions in the Western North Pacific during the ENSO events. Journal of the Meteorological Society of Japan 66, 445-456.

He B., Olack G. A., Colman A. S. (2012) Pressure baseline correction and high-precision $\mathrm{CO}_{2}$ clumpedisotope $\left(\Delta_{47}\right)$ measurements in bellows and micro-volume modes. Rapid Commun. Mass Spectrom. 26, 2837-2853.

Hirose N., Fukudome K. (2006) Monitoring the Tsushima Warm Current improves seasonal prediction of the regional snowfall. SOLA 2, 61-63.

Hori M., Ishikawa T., Nagaishi K., Lin K., Wang B.-S., You C.-F., Shen C.-C., Kano A. (2013) Prior calcite precipitation and source mixing process influence $\mathrm{Sr} / \mathrm{Ca}, \mathrm{Ba} / \mathrm{Ca}$ and ${ }^{87} \mathrm{Sr} /{ }^{86} \mathrm{Sr}$ of a stalagmite developed in southwestern Japan during $18.04 .5 \mathrm{ka}$. Chem. Geol. 347, 190-198.

Hori M., Ishikawa T., Nagaishi K., You C.-F., Huang K.-F., Shen C.-C., Kano A. (2014) Rare earth elements in a stalagmite from southwestern Japan: A potential proxy for chemical weathering. Geochem. Jour. 48, 73-84.

Hori M., Kawai T., Matsuoka J., Kano A. (2009) Intra-annual perturbations of stable isotopes in tufas: Effects of hydrological processes. Geochim. Cosmochim. Acta 73, 1684-1695.

Horita J., Wesolowski D. J. (1994) Liquid-vapor fractionation of oxygen and hydrogen isotopes of water from the freezing to the critical temperature. Geochim. Cosmochim. Acta 58, 3425-3437.

Kajita S., Aoyama S., Kitamura T., Hibino M. (1971) The catalogue of limestone caves, Gifu Prefecture, Central Japan 2 (in Japanese). Science report of the Faculty of Education, Gifu University. Natural science 4, 379-386.

Kano A., Matsuoka J., Kojo T., Fujii H. (2003) Origin of annual laminations in tufa deposits, southwest Japan. Palaeogeogr. Palaeoclimatol. Palaeoecol. 191, 243-262.

Kano A., Okumura T., Takashima C. Shiraishi F. (2019) Geobiochenimal Properties of Travertine with Focus on Japanese Sites. Springer, Singapore.

Kawai T., Kano A., Matsuoka J., Ihara T. (2006) Seasonal variation in water chemistry and depositional processes in a tufa-bearing stream in SW-Japan, based on 5 years of monthly observations. Chem. Geol. $232,33-53$.

Kato H., Amekawa S., Kano A., Mori T., Kuwahara Y., Quade J. (2019) Seasonal temperature changes obtained from carbonate clumped isotopes of annually laminated tufas from Japan: Discrepancy between natural and synthetic calcites. Geochim. Cosmochim. Acta 244, 548-564.

Kato H., Amekawa S., Hori M., Shen C.-C., Kuwahara Y., Senda R., Kano A. (2021) Influences of temperature and the meteoric water $\delta^{18} \mathrm{O}$ value on a stalagmite record in the last deglacial to middle 
Holocene period from southwestern Japan. Quat. Sci. Rev. 253, 106746.

Kelson J., Huntington K. W., Schauer A., Saenger C., Lechler A. R. (2017) Toward a universal carbonate clumped isotope calibration: Diverse synthesis and preparatory methods suggest a single temperature relationship. Geochim. Cosmochim. Acta 197, 104-131.

Kawahata H., Ohshima H., Kuroyanagi A. (2011) Terrestrial-Ocean environmental change in the northwestern Pacific from the glacial times to Holocene. J. Asian Earth Sci. 40, 1189-1202.

Kigoshi T., Kumon F., Hayashi R., Kuriyama M., Yamada K., Takemura K. (2014) Climate changes for the past 52 ka clarified by total organic carbon concentrations and pollen composition in Lake Biwa, Japan. Quat. Int. 333, 2-12.

Kluge T., Affek H. P. (2012) Quantifying kinetic fractionation in Bunker Cave speleothems using $\Delta_{47}$. Quat. Sci. Rev. 49, 82-94.

Kluge T., Affek H. P., Marx T., Aeschbach-Hertig W., Riechelmann D. F. C., Scholz D., Riechelmann S., Immenhauser A., Richter D. K., Fohlmeister J., Wackerbarth A., Mangini A., Spötl C. (2013) Reconstruction of drip-water $\delta^{18} \mathrm{O}$ based on calcite oxygen and clumped isotopes of speleothems from Bunker Cave (Germany). Climate of the Past 9, 377-391.

Kluge T., John C. M., Jourdan A.-L., Davis S., Crawshaw J. (2015) Laboratory calibration of the calcium carbonate clumped isotope thermometer in the $25-250^{\circ} \mathrm{C}$ temperature range. Geochim. Cosmochim. Acta 157, 213-227.

Liu X., Dong H., Yang X., Herzschuh U., Zhang E., Stuut J.-B.W., Wang Y. (2009) Late Holocene forcing of the Asian winter and summer monsoon as evidenced by proxy records from the northern Qinghai-Tibetan Plateau. Earth and Planetary Science Letters 280, 276-284.

Meckler A. N., Affolter S., Dublyansky Y. V., Krüger Y., Vogel N., Bernasconi S. M., Frenz M., Kipfer R., Leuenberger M., Spötl C., Carolin S., Cobb K. M., Moerman J., Adkins J. F., Fleitman D. (2015) Glacial】 interglacial temperature change in the tropical West Pacific: A comparison of stalagmite-based paleothermometers. Quat. Sci. Rev. 127, 90-116.

Mori T., Kashiwagi K., Amekawa S., Kato H., Okumura T., Takashima C., Wu C.-C., Shen C.-C., Quade J., Kano A. (2018) Temperature and seawater isotopic controls on two stalagmite records since 83 ka from maritime Japan. Quat. Sci. Rev. 192, 47-58.

Nakagawa T., Tarasov P. E. Nishida K., Gotanda K., Yasuda Y. (2002) Quantitative pollen-based climate reconstruction in central Japan: application to surface and Late Quaternary spectra. Quat. Sci. Rev. 21, 2099-2113. 
Nakamura Y., Inouchi Y., Inoue T., Kondo Y., Kumon F., Nagahashi Y. (2013) Lake-level changes and their factors during the last 45,000 years in Lake Nojiri, Central Japan (in Japanese). The Quaternary Research (Daiyonki-Kenkyu) 52, 203-212.

Schauble E. A., Ghosh P., Eiler J. M. (2006) Preferential formation of ${ }^{13} \mathrm{C}-{ }^{18} \mathrm{O}$ bonds in carbonate minerals, estimated using first-principles lattice dynamics. Geochim. Cosmochim. Acta 70, 2510-2529.

Scholz D., Hoffmann D. L. (2011) StalAge - An algorithm designed for construction of speleothem age models. Quat. Geochronol. 6, 369-382.

Schrag D. P., Adkins J. F., McIntyre K., Alexander J. L., Hodell D. A., Charles C. D., McManus J. F. (2002) The oxygen isotopic composition of seawater during the Last Glacial Maximum. Quat. Sci. Rev. 21, 331342.

Schrag D. P., Hampt G., Murray D. W. (1996) Pore Fluid Constraints on the Temperature and Oxygen Isotopic Composition of the Glacial Ocean. Science 272, 1930-1932

Shakun J. D., Lea D. W., Lisiecki L. E., Raymo M. E. (2015) An 800-kyr record of global surface ocean $\delta^{18} 0$ and implications for ice volume-temperature coupling. Earth Planet. Sci. Lett. 426 58-68.

Shen C.-C., Kano A., Hori M., Lin K., Chiu T.-C., Burr G. S. (2010) East Asian monsoon evolution and reconciliation of climate records from Japan and Greenland during the last deglaciation. Quat. Sci. Rev. $29,3327-3335$.

Steinke S., Glatz C., Mohtadi M., Groeneveld J., Li Q., Jian Z. (2011) Past dynamics of the East Asian monsoon: No inverse behaviour between the summer and winter monsoon during the Holocene. Global and Planetary Change 78, 170-177.

Tang J., Dietzel M., Fernandez A., Tripati A. K., Rosenheim B. E. (2014) Evaluation of kinetic effects on clumped isotope fractionation $\left(\Delta_{47}\right)$ during inorganic calcite precipitation. Geochim. Cosmochim. Acta $134,120-136$.

Tremaine D. M., Froelich P. N., Wang Y. (2011) Speleothem calcite farmed in situ: modern calibration of $\delta^{18} \mathrm{O}$ and $\delta^{13} \mathrm{C}$ paleoclimate proxies in a continuously-monitored natural cave system. Geochim. Cosmochim. Acta 75, 4929-4950.

Uemura R., Nakamoto M., Asami R., Mishima S., Gibo M., Msaka K., Chen J.-P., Wu C.-C., Chang Y.-W., Shen C.-C. (2016) Precise oxygen and hydrogen isotope determination in nanoliter quantities of speleothem inclusion water by cavity ring-down spectroscopic techniques. Geochim. Cosmochim. Acta 172, 159176.

Wainer K., Genty D., Blamart D., Daëron M., Bar-Matthews M., Vonhof H., Dublyansky Y., Pons-Branchu E., Thomas L., van Calsteren P., Quinif Y., Caillon N. (2011). Speleothem record of the last 180 ka in Villars 
cave (SW France): Investigation of a large $\delta^{18} 0$ shift between MIS6 and MIS5. Quat. Sci. Rev. 30, 130146.

Wang Y. J., Cheng H., Edwards R. L., An Z. S., Wu J. Y., Shen C.-C. and Dorale J. A. (2001) A HighResolution Absolute-Dated Late Pleistocene Monsoon Record from Hulu Cave, China. Science 451, 1090 1093.

Wanner H., Beer J., Bütikofer J., Crowley T. J., Cubasch U., Flückiger J., Goosse H., Grosjean M., Joos F., Kaplan J. O., Küttel M., Müller S. A., Prentice I. C., Solomina O., Stocker T. F., Tarasov P., Wagner M., Widmann M. (2008) Mid- to Late Holocene climate change: An overview. Quat. Sci. Rev. 27, 1791-1828.

Yura K. (2011) Visit and consideration of Ohtaki Limestone Cave (tourism cave), Gujo City, Gifu Prefecture (in Japanese). Cave Environmental NET Society 2, 3-10.

Xiao J., Porter S. C., An Z., Kumai H., Yoshikawa S. (1995) Grain size of quartz as an indicator of winter monsoon strength on the Loess Plateau of central China during the last 130,000 yr. Quaternary Research $43,22-29$.

Yan M., Liu Z. Y., Ning L., Liu J. (2020) Holocene EASM-EAWM relationship across different timescales in CCSM3. Geophys. Res. Lett. 47, e2020GL088451.

Yancheva G., Nowaczyk N. R., Mingram J., Dulski P., Schettler G., Negendank J. F. W., Liu J., Sigman D. M., Peterson L. C., Haug G. H. (2007) Influence of the intertropical convergence zone on the East Asian monsoon. Nature 445, 74-77.

Zaarur S., Affek H. P., Brandon M. T. (2013) A revised calibration of the clumped isotope thermometer. Earth Planet. Sci. Lett. 383, 47-57.

Zhang, D., Lu, L. (2007). Anti-correlation of summer/winter monsoons? Nature, 450, E7-E8.

\section{Tables}

Due to technical limitations, table 1 is only available as a download in the Supplemental Files section.

\section{Figures}




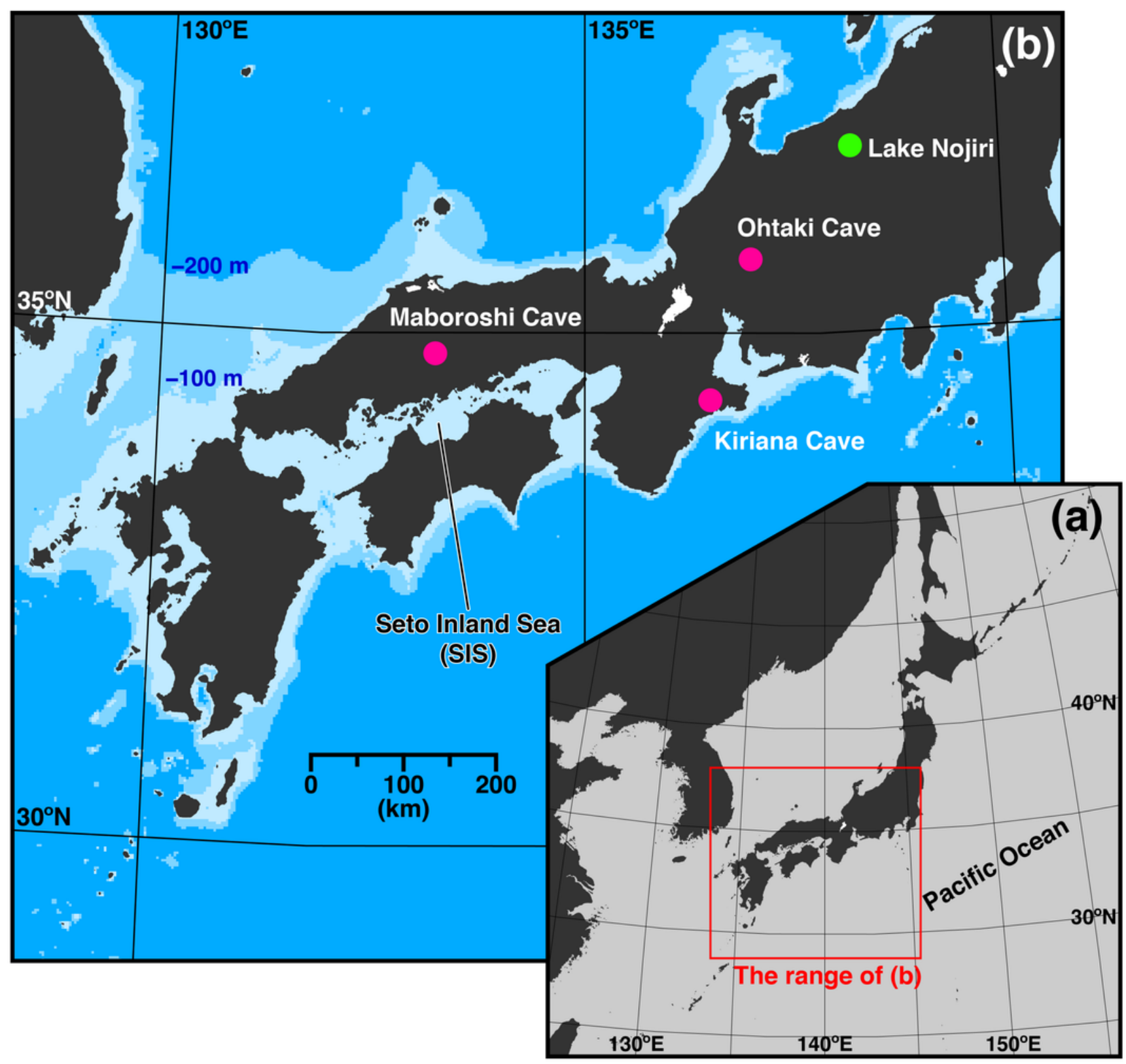

\section{Figure 1}

Maps of study sites. (a) Location of our study area and (b) bathymetric map of western Japan showing the locations of Ohtaki Cave, Maboroshi Cave, Kiriana Cave, and Lake Nojiri. 


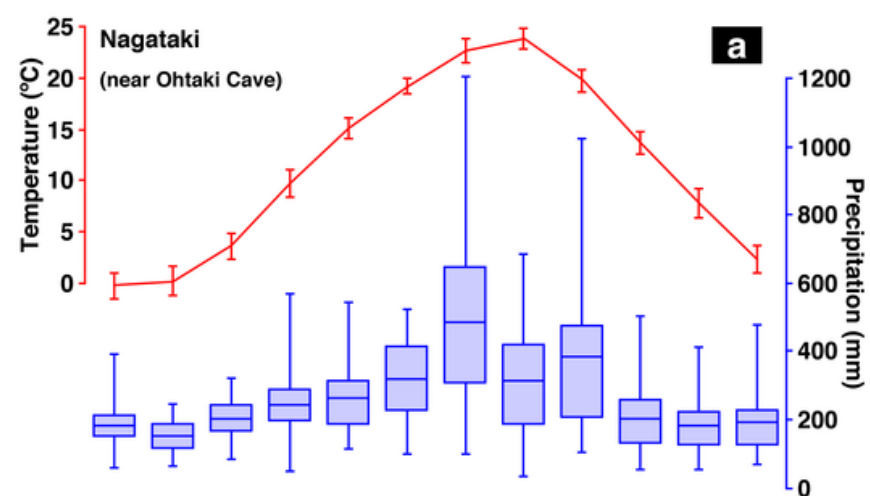

\begin{tabular}{|l|l|l|l|l|l|l|l|l|l|l|l|}
\hline J & $F$ & M & $A$ & M & J & J & $A$ & S & O & N & D \\
\hline
\end{tabular}

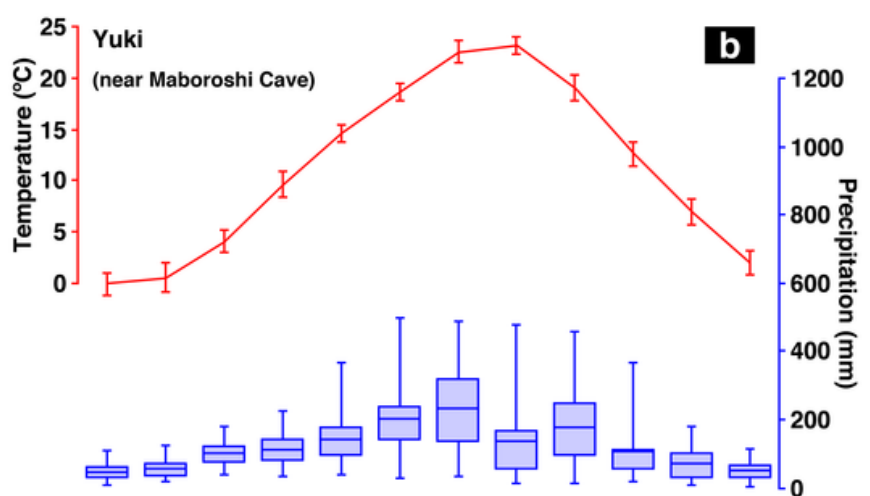

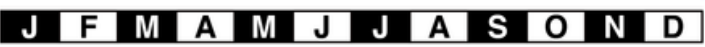

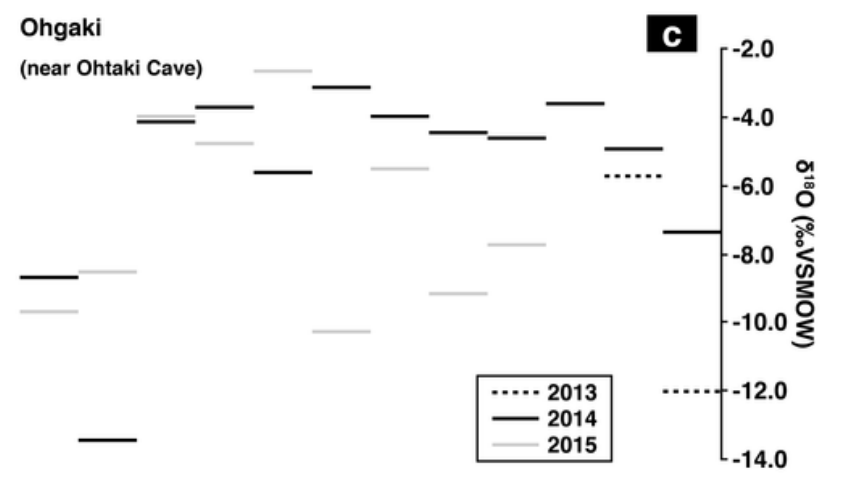

\begin{tabular}{|l|l|l|l|l|l|l|l|l|l|l|l|}
\hline$J$ & $F$ & $M$ & $A$ & $M$ & $J$ & $J$ & $A$ & $S$ & $O$ & $N$ & $D$ \\
\hline
\end{tabular}

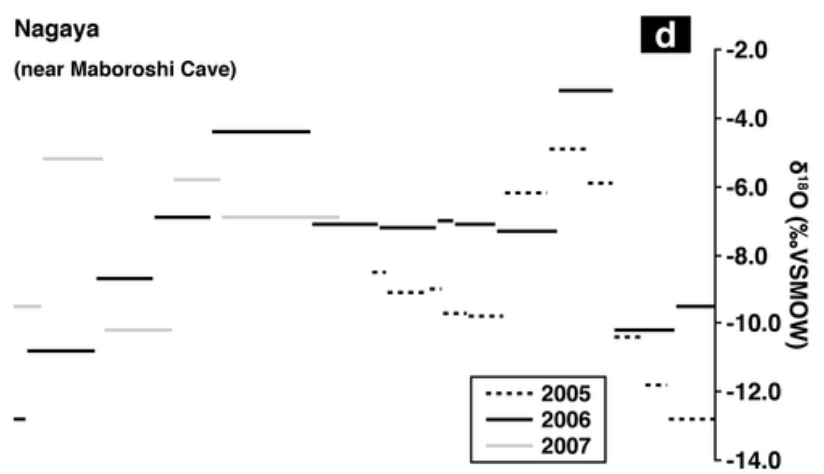

\begin{tabular}{|l|l|l|l|l|l|l|l|l|l|l|l|}
\hline J & $F$ & M & $A$ & M & J & J & $A$ & S & O & N & D \\
\hline
\end{tabular}

Figure 2

Climatic conditions at the Nagataki (a) and Yuki (b) observatories over the period 1981-2020 and oxygen isotopic compositions of meteoric water at Ohgaki (c) and Nagaya (d). (a, b) Average monthly air temperatures are shown with errors of $1 \sigma$. The box plot of precipitation shows the first and third quartiles, and the whisker lengths depict the ranges between the minimum and maximum values. Averaged monthly precipitation is shown by horizontal bars in the boxes. (c, d) Rainwater was collected for each rain event at Ohgaki city, $60 \mathrm{~km}$ southwest from Ohtaki Cave, by Mori et al. (2018) and for each month at Nagaya, 20 km east from Maboroshi Cave, by Hori et al. (2009). The bars in (c) show the weighted average values for each month. 

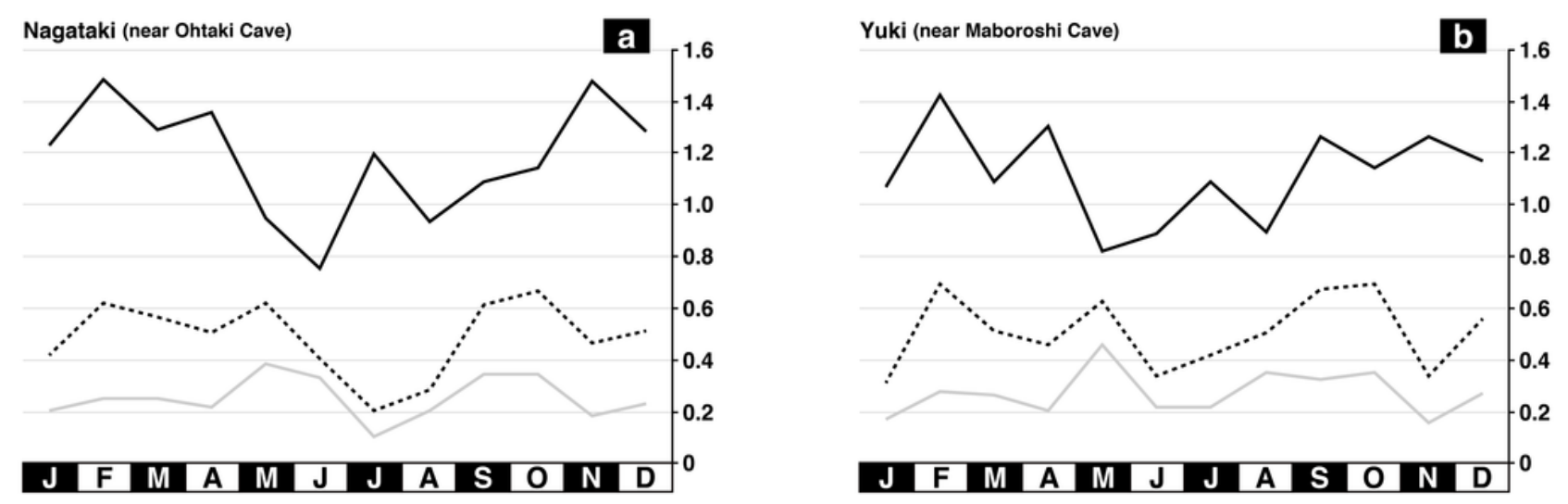

\section{Figure 3}

Relationship between monthly temperature and annual mean temperature in Nagataki (a) and Yuki (b) based on data for the period 1981-2020. Black lines show standard deviations in monthly mean temperature $(1 \sigma)$. Dashed lines show the correlation coefficient $(R)$ between monthly and annual mean temperatures. Gray lines show the impacts of monthly temperatures on the annual average $\left({ }^{\circ} \mathrm{C} /{ }^{\circ} \mathrm{C}\right)$. 

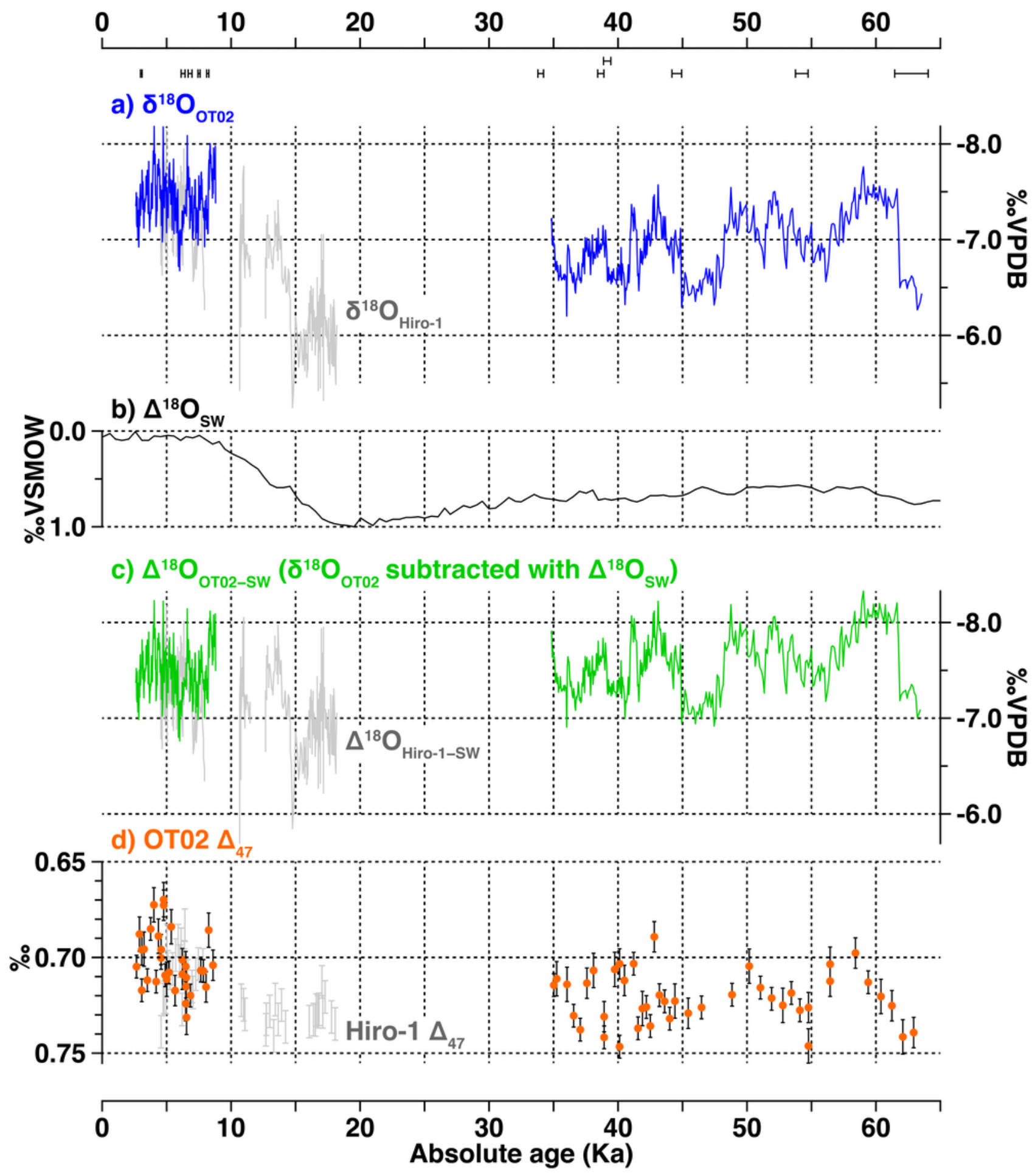

Figure 4

Time series changes of $\delta 1800 T 02$ (a; Mori et al., 2018), $8180 S W$ (b; modified from Lisiecki and Stern, 2016), $\Delta 1800 T 02-S W(\mathrm{c})$, and $\Delta 47$ of ОT02 (d). The error bars of $\Delta 47$ show the SD of in-house standard measurements $( \pm \%$ o). Data for OT02 (a, c, and d) are shown alongside $\delta 180 H i r o-1(a), \Delta 180 H i r o-1-S W$ (c), and $\Delta 47$ of Hiro-1 (Hori et al., 2013; Kato et al., 2021) as gray lines and bars. 

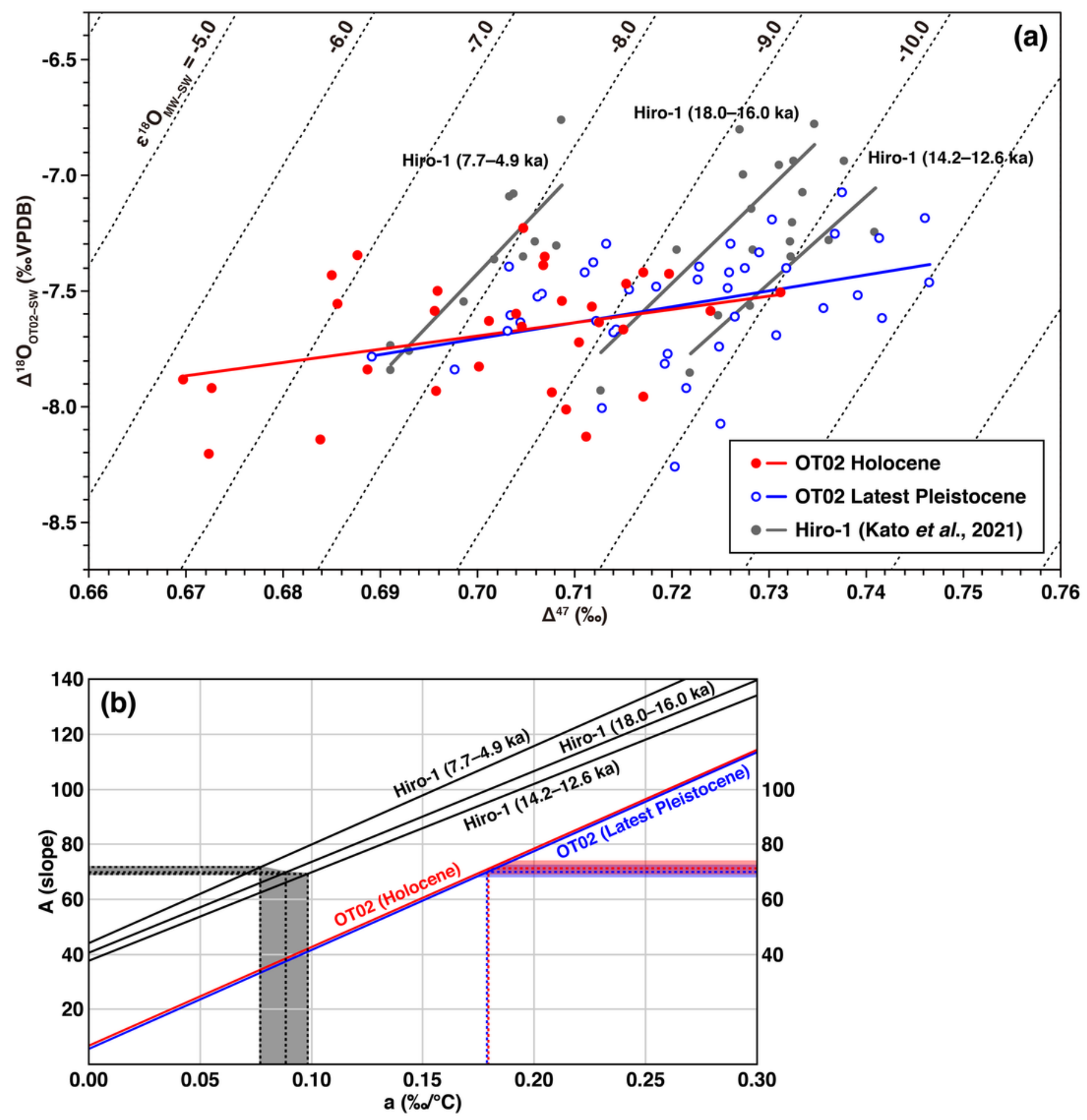

Figure 5

(a) Cross-plot of OT02 $\Delta 47$ and $\Delta 1800 T 02-S W$. Dashed lines show the theoretical relationships at stable $\varepsilon 180 \mathrm{MW}-\mathrm{SW}$ values from $-13.0 \%$ o to $-4.0 \%$ o (VSMOW), calculated using equations 3 and 4 (Kato et al., 2019; Tremaine et al., 2011). Regression lines of OT02 are given for the Holocene (in red) and latest Pleistocene (in blue) and are indistinguishable from each other. The slopes of these lines are clearly shallower than the theoretical relationships and the three discrete regression lines for the Hiro-1 
stalagmite (Kato et al., 2021). (b) Slopes of regression lines (A in Eq. 6) between $\Delta 47$ and ( $\triangle 1800 T 02-S W-F T S W-M W)$ under variable temperature dependency of FTSW-MW (a in Eq. 7). The a value for 0T02 is $0.18\left(\% /{ }^{\circ} \mathrm{C}\right)$, which is clearly larger than that for Hiro- $1,0.08-0.10\left(\% /{ }^{\circ} \mathrm{C}\right.$; Kato et al., 2021).
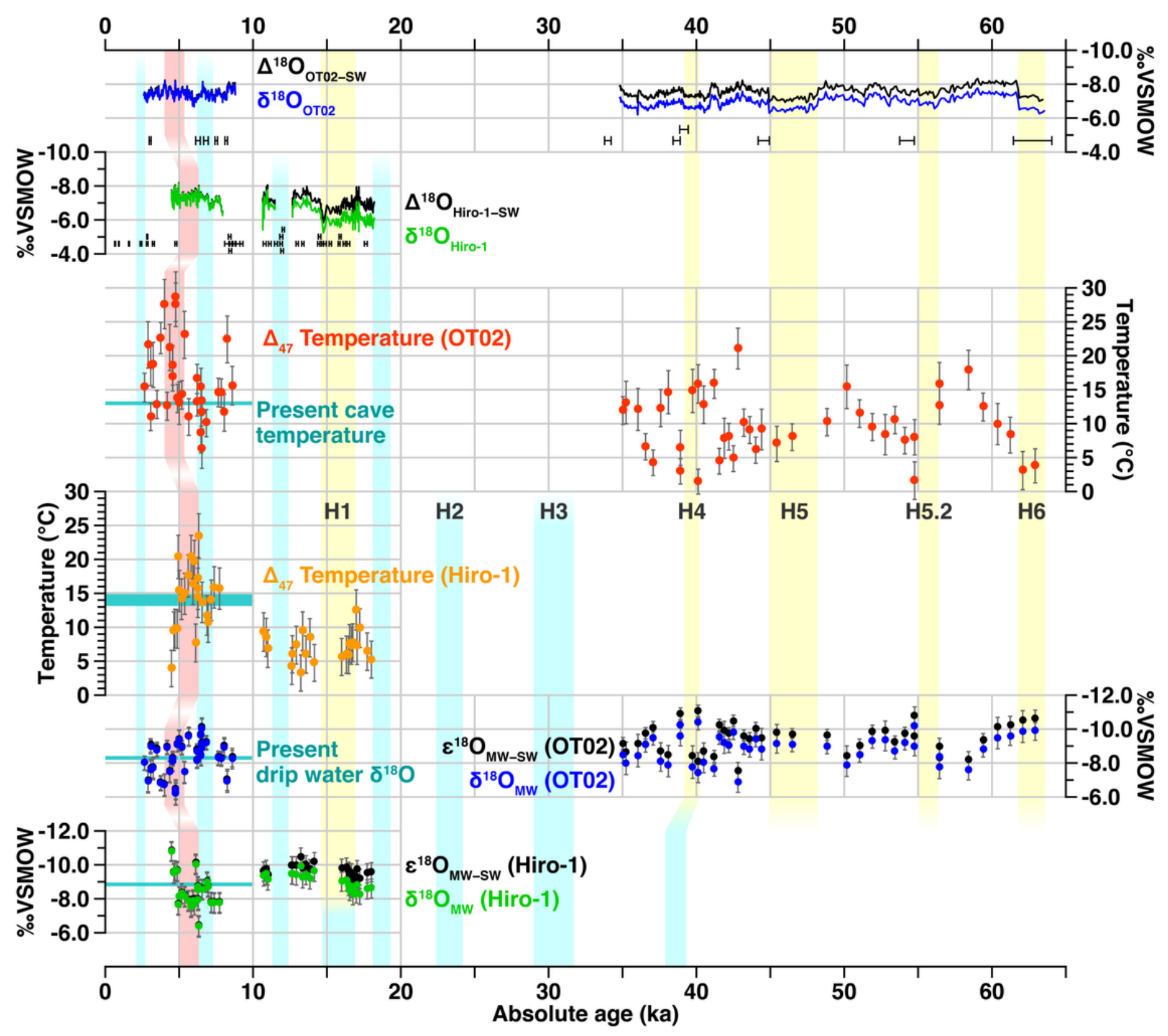

Figure 6

$\triangle 47$ temperature and $8180 \mathrm{MW}$ and $\varepsilon 180 \mathrm{MW}$-SW from the OT02 stalagmite compared with the results of the Hiro-1 stalagmite (Kato et al., 2021). Yellow vertical bands show periods of Heinrich cooling. Light blue bands show periods of high lake level in Lake Nojiri, which occurs after heavy snowfall from EAWM as revealed by Nakamura et al. (2013). The light red band shows a period of warm climatic optimum corresponding to the Hypsithermal observed both in this study and in the Hiro-1 stalagmite of Kato et al. (2021). 


\section{Supplementary Files}

This is a list of supplementary files associated with this preprint. Click to download.

- OT02graphicalabstract.pdf

- Table1.xlsx 